\title{
Nutrient demand interacts with forage family to affect digestion responses in dairy cows
}

\author{
K. L. Kammes and M. S. Allen ${ }^{1}$ \\ Department of Animal Science, Michigan State University, East Lansing 48824-1225
}

\begin{abstract}
Effects of forage family on dry matter intake (DMI), milk production, ruminal pool sizes, digestion and passage kinetics, and chewing activity and the relationship of these effects with preliminary DMI (pDMI), an index of nutrient demand, were evaluated using 13 ruminally and duodenally cannulated Holstein cows in a crossover design with a 14-d preliminary period and two 18-d treatment periods. During the preliminary period, pDMI of individual cows ranged from 19.6 to $29.5 \mathrm{~kg} / \mathrm{d}$ $($ mean $=25.9 \mathrm{~kg} / \mathrm{d})$ and $3.5 \%$ fat-corrected milk yield ranged from 24.3 to $60.3 \mathrm{~kg} / \mathrm{d}$ (mean $=42.1 \mathrm{~kg} / \mathrm{d}$ ). Experimental treatments were diets containing either a) alfalfa silage $(\mathrm{AL})$ or $\mathrm{b}$ ) orchardgrass silage (OG) as the sole forage. Alfalfa and orchardgrass contained 42.3 and $58.2 \%$ neutral detergent fiber (NDF) and 22.5 and $11.4 \%$ crude protein, respectively. Forage:concentrate ratios were 60:40 and 43:57 for AL and OG, respectively; both diets contained approximately $25 \%$ forage NDF and $30 \%$ total NDF. Preliminary DMI was determined during the last $4 \mathrm{~d}$ of the preliminary period when cows were fed a common diet and used as a covariate. Main effects of forage family and their interaction with pDMI were tested by ANOVA. Forage family and its interaction with pDMI did not affect feed intake, milk yield, or milk composition. The AL diet increased indigestible NDF (iNDF) intake and decreased potentially digestible NDF (pdNDF) intake compared with OG. The AL diet increased ruminal $\mathrm{pH}$, digestion rates of pdNDF and starch, and passage rates of pdNDF and iNDF compared with OG, which affected ruminal digestibility. Passage rate of iNDF was related to $\mathrm{pDMI}$; $\mathrm{AL}$ increased iNDF passage rate and OG decreased it as pDMI increased. The AL diet decreased ruminal pool sizes of pdNDF, starch, organic matter, dry matter, and rumen digesta wet weight and volume compared with OG. The AL diet decreased ruminating time per unit of forage NDF consumed compared with OG, indicating that alfalfa provided less physically effective
\end{abstract}

Received October 5, 2011.

Accepted January 24, 2012.

${ }^{1}$ Corresponding author: allenm@msu.edu fiber than orchardgrass. The AL diet, but not OG, increased ammonia $\mathrm{N}$, nonammonia nonmicrobial $\mathrm{N}$, and nonammonia $\mathrm{N}$ fluxes as pDMI increased. Efficiency of microbial protein synthesis was positively related to pdNDF passage rate for OG, but not AL. The faster rates of digestion and passage for $\mathrm{AL}$ compared with OG decreased rumen pool size but did not increase feed intake for cows consuming AL. Digestion responses to forage family were affected by nutrient demand of cows. Key words: forage family, alfalfa versus grass, rate of passage, digestion kinetics

\section{INTRODUCTION}

Utilization of diets by dairy cows is largely influenced by the nutrient composition and physical characteristics of the forage in the ration. Large differences exist among forage families (grasses and legumes) including chemical composition, anatomical characteristics, and digestion characteristics that affect digestibility (Allen, 1996; Wilson and Kennedy, 1996). Cool-season grasses and legumes differ in concentration and the rate and extent of digestion of fiber (Van Soest, 1982). Grasses generally contain higher total NDF and potentially digestible NDF (pdNDF) concentrations, which have a slower rate of digestion but greater extent of digestion than legumes (Buxton and Redfearn, 1997). Grass particles are more resistant to breakdown than are alfalfa particles (Wilson and Hatfield, 1997), and cows spend more time ruminating grasses than legumes (Buxton and Redfearn, 1997), which can affect rumen $\mathrm{pH}$ and fiber digestion (Allen, 1997). Although the greater extent of digestion for grasses offers potential for greater energy availability, slower digestion rates can result in greater ruminal retention times and subsequently lower intake, possibly offsetting gains from higher digestibility (Allen, 2000).

In general, lactating dairy cows fed grass-based diets have lower DMI and milk production compared with cows fed legume-based diets (Oba and Allen, 1999; Steinshamn, 2010). However, many lactation studies comparing legumes with grasses reported in the literature are confounded by the NDF differences between the 2 species. When diets are formulated to contain 
an equal amount of forage DM, total and forage NDF concentrations of diets generally will be higher for diets containing grasses compared with legumes. Increasing dietary NDF concentration often has a negative impact on the amount of DM consumed by lactating dairy cows (Allen, 2000). In this experiment, rations were formulated to contain similar forage NDF concentrations to specifically measure the effects of forage fiber across forage family. Alfalfa (Medicago sativa) and orchardgrass (Dactylis glomerata L.) were selected as a representative legume and cool-season grass, respectively.

In addition to the combination of dietary factors affecting ruminal digestion and distention, the individual cow's appetite will also affect the responses of passage rate and intake to forage family. Voelker Linton and Allen (2008) found that the response of DMI to forage family depended on the appetite of individual cows, as intake was more restricted by orchardgrass than alfalfa as level of intake increased. Because forage family and level of intake affect ruminal passage and digestion rates and, thus, digesta fill in the rumen, the response to effects of forage family and its relationship with intake level was assessed to determine if responses to treatment vary among cows with a wide range in DMI. We hypothesized that responses of DMI and passage rates to forage family are related to level of intake and legumes will permit a greater increase in passage rate than grasses as feed intake increases.

The objectives of this experiment were to evaluate the relationships between voluntary DMI and effects of forage family on DMI, milk production, ruminal fermentation and pool sizes, digestion and passage kinetics, and chewing behavior in lactating dairy cows. This study had 3 unique features to improve our understanding of the role of forage family and interpret its effect on animal responses. First, it allowed effects of the interaction between forage family and preliminary DMI (pDMI) to be evaluated. The use of pDMI, an index of nutrient demand, allowed the evaluation of treatments on animal responses in relation to level of intake and provided an indicator to test effects of intake level independent of treatments. Second, it directly compared treatment effects of alfalfa and orchardgrass as the sole source of forage. Third, ruminal passage rates of individual nutrient fractions, instead of entire feeds, were measured using ruminally and duodenally cannulated cows.

\section{MATERIALS AND METHODS}

This article is the first of 2 from one experiment that evaluated the effects of forage family and its interaction with level of feed intake (nutrient demand). This article discusses the effect of $\mathrm{pDMI}$ on responses to treatment for production, rumen parameters and kinetics, and chewing activity. The companion article focuses on rates of particle size breakdown in, and particle passage from, the rumen (Kammes and Allen, 2012).

\section{Cows and Treatments}

Experimental procedures were approved by the Institutional Animal Care and Use Committee at Michigan State University (East Lansing). Thirteen multiparous Holstein cows from the Michigan State University Dairy Cattle Teaching and Research Center were assigned randomly to treatment sequence in a crossover design experiment with one 14-d preliminary period and two 18-d experimental periods. The first $10 \mathrm{~d}$ of each period were allowed for diet adaptation and samples were collected during the final $4 \mathrm{~d}$ of the preliminary period and $8 \mathrm{~d}$ of each experimental period. Cows were 157 \pm 90 (mean \pm SD) DIM at the end of the preliminary period and were selected to provide a wide range and uniform distribution of pDMI and milk yield. During the final $4 \mathrm{~d}$ of the 14-d preliminary period, the average pDMI among cows ranged from 19.6 to $29.5 \mathrm{~kg} / \mathrm{d}$ $($ mean $=25.9 \mathrm{~kg} / \mathrm{d})$ and $3.5 \% \mathrm{FCM}$ yield ranged from 24.3 to $60.3 \mathrm{~kg} / \mathrm{d}($ mean $=42.1 \mathrm{~kg} / \mathrm{d}$; Table 1$)$. Prior to calving, cows were cannulated ruminally (Bar Diamond Inc., Parma, ID) and duodenally with a gutter-type $\mathrm{T}$ cannula placed approximately $10 \mathrm{~cm}$ distal to the pylorus (Joy et al., 1997). Surgery was performed at the Department of Large Animal Clinical Science, College of Veterinary Medicine, Michigan State University.

Experimental treatments were diets containing either a) alfalfa silage (AL) or b) orchardgrass silage ( $\mathbf{O G}$ ) as the sole forage. Alfalfa (Pioneer 54H91; Pioneer Hi-Bred, Johnston, IA) and orchardgrass (Baridana cultivar; Barenbrug USA, Tangent, OR) were produced (>99\% pure) at the campus farm at Michigan State University (East Lansing), and second cuttings were harvested at early to mid-bloom and early-head stages, respectively. Both forages were chopped to $10-\mathrm{mm}$ theoretical length of cut, and ensiled in Ag-Bags (AgBag Systems Inc., St. Nazianz, WI) a minimum of 75 $\mathrm{d}$ before feeding. During the sample collection periods, alfalfa and orchardgrass contained 42.3 and $58.2 \%$ NDF and 22.5 and $11.4 \% \mathrm{CP}$, respectively (DM basis; Table 2). Diets AL and OG were formulated to contain $25 \%$ forage NDF, $30 \%$ total NDF, and $18 \% \mathrm{CP}$. We acknowledge that these treatments affect dietary starch concentration, but maintaining similar forage and total NDF concentrations for both treatments was of primary interest. The diet fed during the preliminary period was formulated so that alfalfa and orchardgrass each contributed $50 \%$ of forage NDF. Diets also contained dry ground corn, SoyPLUS (West Central Soy Cooperative, 
Table 1. Characterization of 13 cows during the final $4 \mathrm{~d}$ of the 14-d preliminary period, when cows were fed a common diet

\begin{tabular}{lccccc}
\hline Parameter & Median & Mean & SD & Minimum & Maximum \\
\hline Parity & 3 & 3.31 & 1.16 & 2 & 5 \\
BW, $^{1} \mathrm{~kg}$ & 591 & 587 & 51 & 489 & 710 \\
BCS & 2.0 & 2.35 & 0.69 & 1.58 & 4.00 \\
DIM & 132 & 157 & 90 & 64 & 337 \\
Milk, kg/d & 41.4 & 41.5 & 10.8 & 22.6 & 57.1 \\
$3.5 \%$ FCM, kg/d & 43.1 & 42.1 & 11.9 & 24.3 & 60.3 \\
DMI, kg/d & 26.7 & 25.9 & 3.0 & 19.6 & 29.5 \\
\hline
\end{tabular}

${ }^{1}$ Empty BW (ruminal digesta removed).

Ralston, IA), and vitamin-mineral premix (Table 3); soybean meal ( $48 \% \mathrm{CP})$, urea, and limestone were used to compensate for lower $\mathrm{CP}$ and $\mathrm{Ca}$ concentrations in orchardgrass silage than in alfalfa silage.

\section{Data and Sample Collection}

Throughout the experiment, cows were housed in tie-stalls and fed diets as TMR once daily $(1130 \mathrm{~h})$

Table 2. Chemical composition, particle size distribution, and fermentation parameters of alfalfa silage and orchardgrass silage included in the treatment diets

\begin{tabular}{|c|c|c|}
\hline Item & Alfalfa & Orchardgrass \\
\hline \multicolumn{3}{|l|}{ Chemical composition } \\
\hline DM, \% & 43.5 & 33.7 \\
\hline OM, \% DM & 91.9 & 90.3 \\
\hline $\mathrm{NDF}, \% \mathrm{DM}$ & 42.3 & 58.2 \\
\hline $\mathrm{iNDF},{ }^{1} \% \mathrm{DM}$ & 23.0 & 16.1 \\
\hline iNDF, $\%$ of NDF & 54.5 & 27.7 \\
\hline $\mathrm{ADF}, \%$ of $\mathrm{DM}$ & 35.0 & 36.4 \\
\hline $\mathrm{ADL}, \%$ of $\mathrm{DM}$ & 7.56 & 6.03 \\
\hline $\mathrm{CP}, \% \mathrm{DM}$ & 22.5 & 11.4 \\
\hline Starch, \% DM & 1.87 & 1.37 \\
\hline NDF digestibility, ${ }^{2} \%$ & 38.3 & 53.3 \\
\hline \multicolumn{3}{|l|}{ Particle size distribution $^{3}$} \\
\hline \multicolumn{3}{|c|}{ Wet sieving, \% DM retained } \\
\hline $19.0 \mathrm{~mm}$ & 21.4 & 12.3 \\
\hline $9.50 \mathrm{~mm}$ & 18.0 & 18.4 \\
\hline $4.75 \mathrm{~mm}$ & 30.8 & 37.2 \\
\hline $2.36 \mathrm{~mm}$ & 17.0 & 21.2 \\
\hline $1.18 \mathrm{~mm}$ & 5.72 & 6.15 \\
\hline $0.600 \mathrm{~mm}$ & 3.09 & 2.08 \\
\hline $0.300 \mathrm{~mm}$ & 1.97 & 1.02 \\
\hline $0.150 \mathrm{~mm}$ & 1.16 & 0.94 \\
\hline $0.075 \mathrm{~mm}$ & 0.40 & 0.37 \\
\hline $0.038 \mathrm{~mm}$ & 0.50 & 0.37 \\
\hline Mean particle size ${ }^{4} \mathrm{~mm}$ & 11.6 & 9.66 \\
\hline \multicolumn{3}{|c|}{ Penn State Particle Separator, \% DM retained } \\
\hline$>19.0 \mathrm{~mm}$ & 29.3 & 17.1 \\
\hline 19.0 to $8.0 \mathrm{~mm}$ & 48.5 & 50.2 \\
\hline$<8.0 \mathrm{~mm}$ & 22.2 & 32.7 \\
\hline \multicolumn{3}{|l|}{ Fermentation } \\
\hline $\mathrm{pH}$ & 4.58 & 4.59 \\
\hline Acetic acid, \% DM & 2.38 & 0.90 \\
\hline Propionic acid, \% DM & 0.35 & 0.07 \\
\hline Butyric acid, \% DM & $<0.01$ & 0.26 \\
\hline Lactic acid, \% DM & 5.94 & 6.10 \\
\hline Lactic acid:acetic acid & 2.49 & 6.78 \\
\hline Ethanol, \% DM & 0.33 & $<0.01$ \\
\hline Ammonia, $\mathrm{m} M$ & 4.65 & 2.86 \\
\hline
\end{tabular}


Table 3. Ingredients and chemical composition of preliminary and treatment diets (as analyzed) containing either alfalfa $(\mathrm{AL})$ or orchardgrass $(\mathrm{OG})$ silage as the sole source of forage

\begin{tabular}{lccc}
\hline Composition & Preliminary & AL & OG \\
\hline Ingredient, \% DM & & & - \\
Alfalfa silage & 30.0 & 59.9 & 42.7 \\
Orchardgrass silage & 21.5 & - & 36.6 \\
Dry ground corn & 36.2 & 33.6 & 11.8 \\
Soybean meal (48\% CP) & 5.81 & - & 3.39 \\
SoyPLUS ${ }^{1}$ & 1.82 & 3.50 & 3.99 \\
Vitamin-mineral mix ${ }^{2}$ & 3.99 & - & 0.30 \\
Urea & 0.15 & - & 1.20 \\
Limestone & 0.60 & 54.5 & 52.3 \\
Chemical composition & & 92.7 & 91.1 \\
DM, \% & 51.6 & 29.2 & 30.2 \\
OM, \% DM & 92.4 & 25.3 & 24.9 \\
NDF, \% DM & 29.1 & 86.8 & 82.3 \\
\% Forage NDF & 24.7 & 14.8 & 8.24 \\
\% NDF from forage & 84.8 & 50.7 & 27.3 \\
iNDF, \% DM & NA & 18.4 & 17.0 \\
iNDF, \% of NDF & NA & 27.3 & 29.6 \\
CP, \% DM & 17.5 & 33.5 & \\
Starch, \% DM & & & \\
\hline
\end{tabular}

${ }^{1}$ West Central Soy Cooperative (Ralston, IA).

${ }^{2}$ Vitamin-mineral mix contained (DM basis) $16.5 \%$ sodium bicarbonate, $14.2 \%$ magnesium sulfate, $7.1 \%$ salt, $5.8 \%$ dicalcium phosphate, $2.4 \%$ trace mineral premix, $0.4 \%$ vitamin $\mathrm{A}, 0.4 \%$ vitamin $\mathrm{D}, 0.2 \%$ vitamin $\mathrm{E}$, and $53.1 \%$ dry ground corn as a carrier.

${ }^{3} \mathrm{iNDF}=$ indigestible NDF

${ }^{4} \mathrm{NA}=$ no analysis for preliminary diet.

at $110 \%$ of expected intake. The amount of feed offered and refused (orts) was weighed daily for each cow. Forage samples were collected twice weekly and analyzed to adjust diets to account for DM, NDF, and CP fluctuation. Samples of all dietary ingredients $(0.5$ $\mathrm{kg}$ ) and orts (12.5\%) were collected daily from d 11 to 14 during the preliminary period and d 11 to 15 during each experimental period. Samples were frozen immediately after collection at $-20^{\circ} \mathrm{C}$ and combined into 1 composite sample per period before analysis.

Cows were moved to an exercise lot twice daily (0230 and $1300 \mathrm{~h}$ ) before milking in a parlor (0400 and 1430 h). Milk yield was measured and milk was sampled at each milking on d 11 to 14 of the preliminary period and on d 11 to 15 of the experimental periods. Rumenempty BW was measured by weighing the cow after evacuation of ruminal digesta on d 14 of the preliminary period and d 18 of each experimental period. Body condition score was determined on the same days by 3 trained investigators blinded to treatments (Wildman et al., 1982; 5-point scale, where $1=$ thin and $5=$ fat). Chewing activity was monitored and recorded by observation every $5 \mathrm{~min}$ for $24 \mathrm{~h}$ on d 16 of each experimental period. Activity was noted as eating, ruminating, drinking, or idle for each cow at each time.

Duodenal samples (900 mL); fecal samples (500 g); rumen fluid and particulate samples for microbial isolation (400 g); rumen fluid samples for $\mathrm{pH}$, concentrations of VFA, lactate, and ammonia $(100 \mathrm{~mL})$; and blood samples for concentrations of glucose, insulin, and glucagon $(12 \mathrm{~mL}$ total) were collected every $15 \mathrm{~h}$ from d 11 to 15 of each experimental period so that 8 samples were taken for each cow in each period, representing every $3 \mathrm{~h}$ of a 24 -h period to account for diurnal variation. Rumen fluid and particulate matter for microbial isolation were collected from the reticulum, near the reticular-omasal orifice, transported to the laboratory, and processed. Rumen fluid for $\mathrm{pH}, \mathrm{VFA}$, lactate, and ammonia analysis was obtained by combining digesta from 5 different sites in the rumen and straining it through nylon mesh ( $\sim 1-\mathrm{mm}$ pore size); fluid $\mathrm{pH}$ was recorded immediately. Blood was sampled from coccygeal vessels and collected into 2 evacuated tubes $(6 \mathrm{~mL}$ each), one containing potassium EDTA and the other containing potassium oxalate with sodium fluoride as a glycolytic inhibitor. Both were centrifuged at 2,000 $\times$ $g$ for 15 min immediately after sample collection and plasma was collected. Samples containing potassium EDTA were preserved with benzamidine (0.05 $M$ final concentration). Samples were stored at $-20^{\circ} \mathrm{C}$.

Ruminal contents were evacuated manually through the ruminal cannula $4 \mathrm{~h}$ after feeding at the beginning of $\mathrm{d} 17(1530 \mathrm{~h})$ and $2 \mathrm{~h}$ before feeding at the end of $\mathrm{d}$ $18(0930 \mathrm{~h})$ for each experimental period. Total rumen content mass and volume were determined. To ensure accurate sampling, every tenth handful of digesta (10\%) was separated for a subsample throughout evacuation. This subsample was squeezed into primarily solid and 
liquid phases. Both phases were weighed and sampled $(350 \mathrm{~mL})$ for determination of nutrient pool size. All samples were stored at $-20^{\circ} \mathrm{C}$.

\section{Sample Analysis and Calculations}

Milk yields recorded at each milking were summed for a daily total, which were averaged for each period. Milk samples were analyzed for fat, true protein, lactose, SNF, and MUN with infrared spectroscopy by Michigan DHIA (East Lansing). Yields of 3.5\% FCM and milk components were calculated using milk yield and component concentrations for each milking, summed for a daily total, and averaged for each period.

Forage samples were combined into 1 composite sample per forage per period. Particle size distribution was determined using the Penn State Particle Separator containing 2 sieves (19 and $8 \mathrm{~mm}$ ) and a pan (Lammers et al., 1996). In addition, samples were wet sieved manually and sequentially through screens with the following aperture sizes: 19.0, 9.50, 4.75, 2.36, 1.18, $0.600,0.300,0.150,0.075$, and $0.038 \mathrm{~mm}$. The fraction of DM retained on the screens from wet sieving was used to calculate mean particle size.

Diet ingredients, orts, and feces were lyophilized (Tri-Philizer MP; FTS Systems Inc., Stone Ridge, NY). All dried samples were ground with a Wiley mill (1-mm screen; Arthur H. Thomas Co., Philadelphia, PA). Dried, ground fecal samples were combined on an equal DM basis into 1 sample per cow per period. Frozen duodenal samples for each cow period $(\mathrm{n}=8)$ were chopped finely using a commercial food processor (84142 Food cutter; Hobart Manufacturing Co., Troy, $\mathrm{OH})$ and subsampled in the frozen state to obtain representative samples. These duodenal subsamples and the $350 \mathrm{~mL}$ of ruminal solid and liquid samples were lyophilized and ground as described above. Dried ruminal solid and liquid samples were recombined according to the original ratio of solid and liquid DM.

Samples were analyzed for ash, NDF, indigestible NDF (iNDF), ADF, acid detergent sulfuric acid lignin (ADL), CP, and starch. Ash concentration was determined after 5 -h combustion at $500^{\circ} \mathrm{C}$ in a muffle furnace. Concentrations of NDF were determined according to Mertens (2002) and ADF and ADL according to Goering and Van Soest (1970). Indigestible NDF was estimated as NDF residue after 240-h in vitro fermentation (Goering and Van Soest, 1970); flasks were reinoculated at $120 \mathrm{~h}$ to ensure a viable microbial population. Forage NDF digestibility was determined by $30-\mathrm{h}$ in vitro fermentation (Goering and Van Soest, 1970). Ruminal fluid for the in vitro incubations was collected from a nonpregnant dry cow fed dry hay only. The fraction of pdNDF was calculated by difference
$(1.00$ - iNDF). Crude protein was analyzed according to Hach et al. (1987). Starch was measured by an enzymatic method (Karkalas, 1985) after samples were gelatinized with sodium hydroxide. Glucose concentration was measured using a glucose oxidase method (Glucose kit \#510; Sigma Chemical Co., St. Louis, MO), and absorbance was determined with a microplate reader (SpectraMax 190; Molecular Devices Corp., Sunnyvale, CA). Concentrations of all nutrients except DM were expressed as percentages of DM, determined by drying at $105^{\circ} \mathrm{C}$ in forced-air oven for more than $8 \mathrm{~h}$.

Duodenal digesta were analyzed for purines and ammonia to estimate microbial $\mathrm{N}$ (MN) flow and nonammonia, nonmicrobial N (NANMN) flow to the duodenum. Purine concentration was used as a microbial marker, and purine-to-MN ratio was estimated by analysis of microbial pellets obtained by differential centrifugation of the rumen fluid and particulate samples collected near the reticulum. Rumen fluid and particulate matter were blended, strained through nylon mesh, and the liquid portion was centrifuged at 500 $\times g$ for $15 \mathrm{~min}$. The supernatant was centrifuged at $18,000 \times g$ for $15 \mathrm{~min}$, and the pellet was washed with $0.9 \% \mathrm{NaCl}$ solution and centrifuged again at $18,000 \times g$ for $15 \mathrm{~min}$, resuspended in water, and lyophilized. Total purines were measured by spectrophotometer (Beckman Instruments Inc., Fullerton, CA) at $260 \mathrm{~nm}$ according to Zinn and Owens (1986). Ammonia concentration was determined for centrifuged duodenal and rumen fluid samples according to Broderick and Kang (1980). Rumen fluid was also analyzed for concentrations of major VFA and lactate by HPLC (Waters Corp., Milford, MA) according to Oba and Allen (2003a).

Dry matter and nutrient intakes were calculated using the composition of feed offered and refused. Ruminal pool sizes $(\mathrm{kg})$ of OM, NDF, iNDF, pdNDF, starch, $\mathrm{MN}$, and NANMN were determined by multiplying the concentration of each component in rumen samples by the ruminal digesta DM mass $(\mathrm{kg})$. Duodenal flows $(\mathrm{kg} / \mathrm{d})$ of DM, OM, total NDF, pdNDF, starch, MN, NANMN, and ammonia $\mathrm{N}$ were determined using iNDF as a flow marker by multiplying iNDF intake $(\mathrm{kg} / \mathrm{d})$ by the ratio between the component and iNDF in duodenal digesta. Duodenal flow of microbial OM was determined as the product of the purines-to-OM ratio in the microbial pellet and the duodenal flow of purines (Oba and Allen, 2003a), and true ruminally digested OM was calculated by subtracting duodenal flow of nonmicrobial OM from OM intake. Duodenal flow of microbial starch was determined as the product of the purines-to-starch ratio in the microbial pellet and the duodenal flow of purines, and true ruminally digested starch was determined by subtracting the duodenal flow of nonmicrobial starch from total starch intake. 
Indigestible NDF was used as an internal marker to estimate nutrient digestibility in the rumen and in the total tract (Cochran et al., 1986). Turnover rate in the rumen, passage rate from the rumen, and ruminal digestion rate of each component was calculated by the following equations:

$$
\begin{gathered}
\text { turnover rate }(\% / \mathrm{h})=100 \times(\text { intake of component/ } \\
\text { ruminal pool of component }) / 24 ;
\end{gathered}
$$

passage rate $(\% / \mathrm{h})=100 \times($ duodenal flow

of component/ruminal pool of component)/24;

digestion rate $(\% / \mathrm{h})=$ turnover rate in the rumen

$$
(\% / \mathrm{h}) \text { - passage rate from the rumen }(\% / \mathrm{h}) \text {. }
$$

Plasma samples were composited into 1 sample per cow per period and analyzed using commercial kits to determine concentrations of insulin (Coat-A-Count; Siemens Healthcare Diagnostics Inc., Deerfield, IL), and glucagon (kit \#GL-32K; Millipore, Billerica, MA). Plasma glucose concentration was analyzed using a glucose oxidase method that combined $10 \mu \mathrm{L}$ of plasma with $250 \mu \mathrm{L}$ of AB solution (Sigma Chemical Co.), and absorbance was determined as described previously for feed and orts samples.

Manually observed chewing activity was summarized by a logic script in Igor Pro (version 6.12; WaveMetrics Inc., Lake Oswego, OR) to generate meal and rumination bout information according to previously established criteria (Dado and Allen, 1994). Variables determined included frequency of meal bouts per day, interval between meals, frequency of ruminating bouts per day, interval between ruminating bouts, eating time per day, ruminating time per day, and total chewing time per day.

\section{Statistical Analysis}

All data were analyzed by using the fit model procedure of JMP (version 8; SAS Institute, Cary, NC). To determine differences between treatments and evaluate interactions of treatment with DMI, where pDMI (calculated as the mean of DMI values on d 11 to 14 of the 14-d preliminary period) was used as the covariate for treatment responses, data were analyzed according to the following model: $\mathrm{Y}_{\mathrm{ijk}}=\mu+\mathrm{C}_{\mathrm{i}}+\mathrm{P}_{\mathrm{j}}+\mathrm{T}_{\mathrm{k}}+\mathrm{PT}_{\mathrm{jk}}+$ $\mathrm{pDMI}+\mathrm{T}_{\mathrm{k}} \mathrm{pDMI}+\mathrm{pDMI}^{2}+\mathrm{T}_{\mathrm{k}} \mathrm{pDMI}^{2}+\mathrm{e}_{\mathrm{ijk}}$, where $\mathrm{Y}_{\mathrm{ijk}}$ is the dependent variable, $\mu$ is the overall mean, $\mathrm{C}_{\mathrm{i}}$ is the random effect of cow ( $\mathrm{i}=1$ to 13 ), $\mathrm{P}_{\mathrm{j}}$ is the fixed effect of period ( $\mathrm{j}=1$ to 2 ), $\mathrm{T}_{\mathrm{k}}$ is the fixed effect of treatment ( $\mathrm{k}=1$ to 2$), \mathrm{PT}_{\mathrm{jk}}$ is the interaction of period and treatment, $\mathrm{pDMI}$ is the linear effect of $\mathrm{pDMI}, \mathrm{T}_{\mathrm{k}} \mathrm{p}$ DMI is the interaction of treatment and pDMI (linear), $\mathrm{pDMI}^{2}$ is the quadratic effect of $\mathrm{pDMI}, \mathrm{T}_{\mathrm{k}} \mathrm{pDMI}^{2}$ is the interaction of treatment and pDMI (quadratic), and $\mathrm{e}_{\mathrm{ijk}}$ is the residual error. Statistical significance for $T_{k} p D M I$ and $\mathrm{T}_{\mathrm{k}} \mathrm{pDMI}^{2}$ indicated treatment differences were related to pDMI. Covariate and interaction terms were removed stepwise from the model if $P>0.20$. Treatment effects and their interaction (linear and quadratic relationships) were declared significant at $P \leq 0.05$ and $P \leq 0.10$, respectively. Tendencies for treatment effects and their interactions were declared at $P \leq 0.10$ and $P$ $\leq 0.15$, respectively.

Sixteen cows started the experiment; however, 2 cows experienced high fevers and had depressed intake after the first experimental period and were removed. Additionally, data from one cow was excluded before statistical analysis because the calculated value for duodenal flow was extremely high for the second experimental period and resulted in unrealistically low ruminal digestibility. Thus, data from 13 cows were statistically analyzed.

\section{RESULTS AND DISCUSSION}

\section{Comparison of Forages and Diets}

Chemical analyses and physical characteristics of ensiled forages are listed in Table 2. As expected, alfalfa had lower concentration of total NDF (42.3 vs. $58.2 \%$ ) but higher concentrations of iNDF (23.0 vs. $16.1 \%$ ), ADL (7.56 vs. $6.03 \%)$, and CP (22.5 vs. $11.4 \%$ ) than orchardgrass. Indigestible NDF for alfalfa (expressed as a percent of NDF) was nearly twice that for orchardgrass ( 54.5 vs. $27.7 \%$ of NDF). In vitro NDF digestibility $(30 \mathrm{~h})$ was 15 percentage units lower for alfalfa than for orchardgrass (38.3 vs. 53.3\%). Alfalfa had higher DM concentration than orchardgrass and was drier than expected because the alfalfa wilted quicker than anticipated and we had to wait for the farm crew to chop the forage. Both silages had similar $\mathrm{pH}$ and underwent lactic acid fermentation, but alfalfa had a lower lactic:acetic acid ratio than orchardgrass. Based on wet sieving, alfalfa had greater mean particle size (11.6 vs. $9.66 \mathrm{~mm})$ than orchardgrass. Additionally, alfalfa contained a larger proportion of particles $>19$ $\mathrm{mm}$ (29.3 vs. $17.1 \%$; top sieve) and smaller proportion of particles $<8 \mathrm{~mm}$ (22.2 vs. $32.7 \%$; bottom pan) than orchardgrass when sieved with the Penn State Particle Separator. Although forages were chopped to the same theoretical length of cut for both silages, the differences in particle size are likely because of differences in 
physical characteristics between the forage species and orientation of stems in the field.

Diet ingredients and chemical composition are shown in Table 3. The preliminary diet contained more alfalfa silage than orchardgrass silage so each forage supplied similar concentrations of forage NDF. Because treatment diets were formulated to contain similar forage $\mathrm{NDF}$, forage:concentrate ratios were different between diets, with ratios of $60: 40$ and 43:57 for AL and OG, respectively. Besides forage source, differences in diets included sources and concentrations of protein supplements and concentrations of limestone and corn grain, which were lower for AL than OG, to account for differences in chemical composition between alfalfa and orchardgrass. The chemical composition of each diet was mathematically calculated according to the proportion of each feed ingredient in the diet and its respective analytical values, and was similar for forage NDF and total NDF concentrations. Despite increasing the concentration of SoyPLUS and adding soybean meal and urea to increase $\mathrm{CP}$ in $\mathrm{OG}$, AL still contained slightly higher concentrations of $\mathrm{CP}$ than $\mathrm{OG}$ because the $\mathrm{CP}$ concentration of soybean meal was lower than expected. Starch concentration was lower for AL because of more forage and less concentrate in the diet for AL compared with OG. Indigestible NDF was higher for AL than $O G$ and is reflective of the iNDF concentration in the forages, which was higher for alfalfa than orchardgrass.
In both diets, forage NDF provided over $82 \%$ of the total diet NDF.

\section{Effects of Forage Family and pDMI}

Forage family and its interaction with pDMI did not affect DMI, milk yield, or milk composition (Table 4). The AL diet decreased efficiency of milk production compared with OG (FCM/DMI, 1.40 vs. 1.47, $P=0.005$ ) because AL numerically increased DMI compared with $\mathrm{OG}(24.2$ vs. $23.2 \mathrm{~kg} / \mathrm{d}, P=0.13)$ to produce similar yields of FCM, and the difference was greatest for cows with high pDMI (interaction $P=$ 0.006; Table 4). Differences in efficiency between AL and OG might be associated with changes in BW, as AL increased and OG decreased BW (6.05 vs. -3.78 $\mathrm{kg}$ over $18 \mathrm{~d}$ period, $P=0.03$; Table 4$)$ or different concentrations of concentrate in the diets.

Our results are not consistent with lower DMI and milk production for lactating dairy cows fed grassbased diets compared with cows fed legume-based diets (Oba and Allen, 1999; Steinshamn, 2010), but they are consistent with Voelker Linton and Allen (2008) who reported no treatment differences for mean milk yield and DMI for cows fed alfalfa or orchardgrass diets. However, Voelker Linton and Allen (2008) found that testing overall means masked important intake differences; response of DMI to treatment varied for cows

Table 4. Milk production and composition, feed intake, and BW change of cows fed treatment diets containing either alfalfa (AL) or orchardgrass $(\mathrm{OG})$ silage as the sole source of forage

\begin{tabular}{|c|c|c|c|c|c|c|c|c|c|}
\hline Item & \multicolumn{2}{|c|}{ Treatment LSM } & $\mathrm{SE}$ & \multicolumn{6}{|c|}{$P$-value ${ }^{1}$} \\
\hline Milk & 35.1 & 35.2 & 2.3 & 0.92 & 0.14 & 0.06 & $\mathrm{NS}^{2}$ & NS & NS \\
\hline $3.5 \% \mathrm{FCM}$ & 36.7 & 36.5 & 2.1 & 0.84 & NS & 0.02 & NS & NS & NS \\
\hline Milk fat & 1.33 & 1.31 & 0.07 & 0.72 & NS & 0.007 & NS & NS & NS \\
\hline SNF & 1.99 & 1.98 & 0.15 & 0.93 & NS & 0.16 & NS & NS & NS \\
\hline \multicolumn{10}{|l|}{ Milk composition, \% } \\
\hline Fat & 3.79 & 3.77 & 0.09 & 0.63 & 0.04 & 0.16 & NS & NS & NS \\
\hline Protein & 3.14 & 3.10 & 0.12 & 0.20 & NS & NS & NS & NS & NS \\
\hline Lactose & 4.83 & 4.81 & 0.14 & 0.68 & NS & 0.28 & NS & 0.10 & NS \\
\hline SNF & 5.82 & 5.80 & 0.17 & 0.63 & NS & 0.25 & NS & 0.11 & NS \\
\hline MUN, mg/dL & 13.4 & 12.7 & 0.4 & 0.22 & NS & NS & NS & NS & NS \\
\hline
\end{tabular}

${ }^{1} P$-values for treatment (Trt), Trt by period interaction (Trt $\times$ period), preliminary DMI (pDMI), Trt by pDMI interaction $($ Trt $\times$ pDMI), quadratic effect of pDMI $(\mathrm{pDMI} \times \mathrm{pDMI})$, and Trt by quadratic effect of $\mathrm{pDMI}($ Trt $\times \mathrm{pDMI} \times \mathrm{pDMI})$.

${ }^{2}$ Nonsignificant, with $P>0.20$; term was removed from the statistical model. 
with different nutrient demands. Cows with low nutrient demand responded more positively to grass than legume, and cows with high nutrient demand responded more positively to legume than grass. These differences likely depended on the extent to which rumen fill limited feed intake of individual cows.

We expected OG to be more filling than AL, causing greater rumen distention and potentially limiting DMI, particularly in cows with high DMI for which ruminal distention is more likely to limit feed intake (Allen, 1996; Voelker Linton and Allen, 2008), but we did not observe that the response of DMI to treatment was related to level of intake as previously shown by Voelker Linton and Allen (2008). The current study had higher concentration of NDF in the OG, higher forage NDF concentration in the diets, and used cows with higher pDMI compared with the previous study from our laboratory. Cows consuming AL and OG had similar NDF intake $(P=0.17$; Table 5$)$, which also was not related to pDMI.

The AL diet decreased pdNDF intake (3.43 vs. 4.89 $\mathrm{kg} / \mathrm{d})$ and increased iNDF intake (3.53 vs. $1.80 \mathrm{~kg} / \mathrm{d}$ ) compared with OG $(P<0.001 ;$ Table 5$)$ because of differences in chemical composition of forages. Intake of iNDF was related to pDMI such that AL increased intake of iNDF at a faster rate than OG as pDMI increased (interaction $P=0.05$; Figure $1 \mathrm{~A}$ ). The AL diet increased rate of ruminal digestion of pdNDF (7.27 vs. $4.74 \% / \mathrm{h}$ ), rate of ruminal passage of pdNDF (2.29 vs. $1.32 \% / \mathrm{h})$, and rate of ruminal passage of iNDF $(3.27$ vs. $2.52 \% / \mathrm{h})$ compared with OG $(P<0.001$; Table 6$)$. The faster passage rates for $\mathrm{AL}$ compared with $\mathrm{OG}$ were associated with greater rate of particle size reduction for AL compared with OG (7.16 vs. $4.67 \% / \mathrm{h}$, $P<0.001 ;$ Kammes and Allen, 2012). These ruminal kinetics resulted in shorter ruminal turnover times of pdNDF (10.9 vs. $17.4 \mathrm{~h}$ ), iNDF (32.0 vs. $41.6 \mathrm{~h}$ ), and DM $(10.5$ vs. $12.8 \mathrm{~h})$ for AL than OG $(P<0.001$; Table 6 ). Additionally, responses of iNDF ruminal passage rate and turnover time to treatment were related to pDMI; as pDMI increased, AL increased rate of iNDF passage and $\mathrm{OG}$ decreased it (interaction $P=0.09$; Figure 1B) and AL decreased iNDF turnover time and OG increased it (interaction $P=0.06$; Figure $1 \mathrm{C}$ ). The increased turnover time of iNDF for OG as feed intake increased is consistent with results reported by Voelker Linton and Allen (2008).

The aforementioned results contributed to the effects of treatment on rumen pool sizes (Table 7). Despite the faster passage rate and turnover time of iNDF for AL,

Table 5. Neutral detergent fiber digestion of cows fed treatment diets containing either alfalfa (AL) or orchardgrass (OG) silage as the sole source of forage

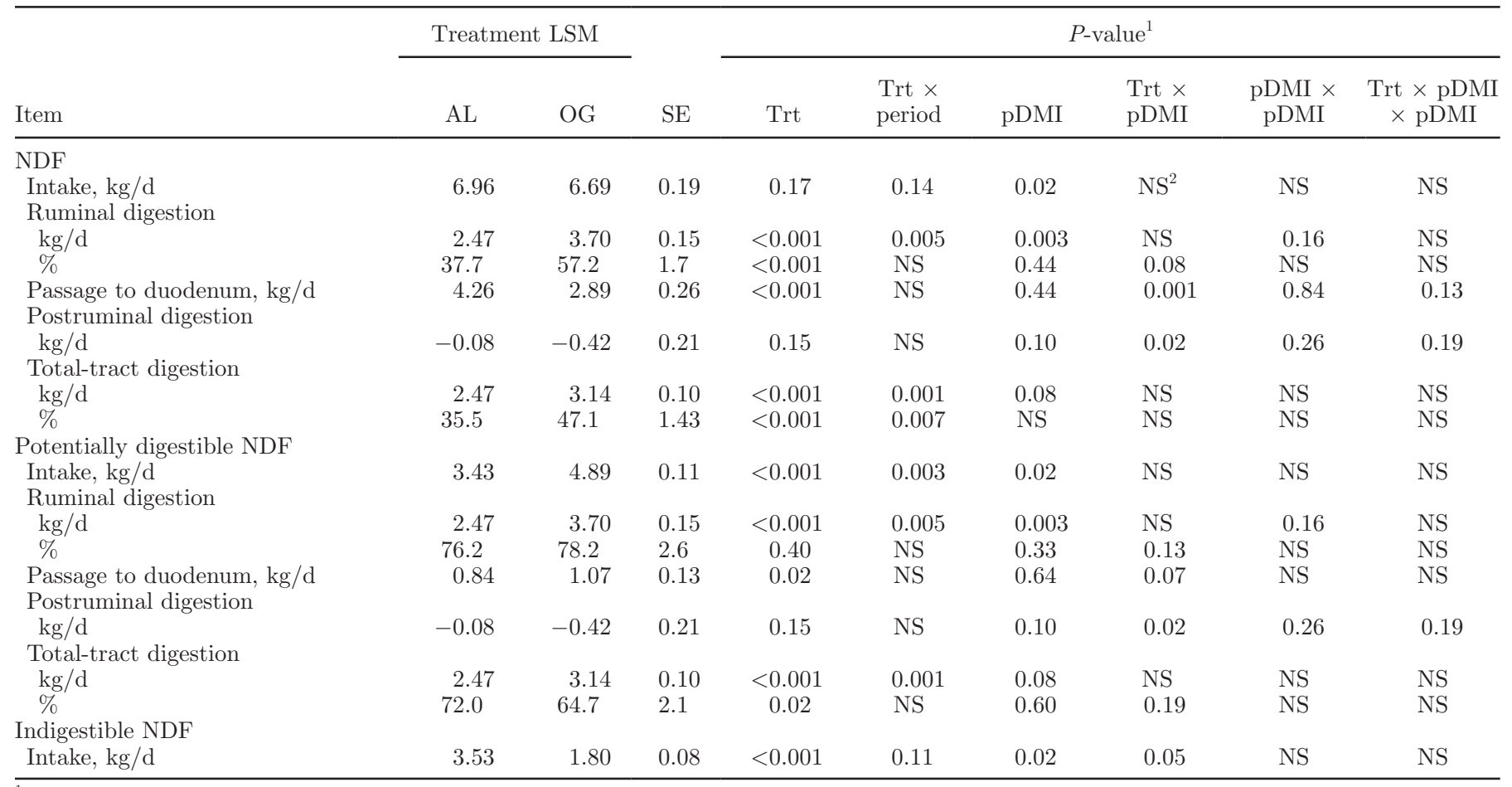

${ }^{1} P$-values for treatment (Trt), Trt by period interaction $($ Trt $\times$ period), preliminary DMI $(\mathrm{pDMI})$, Trt by pDMI interaction $($ Trt $\times$ pDMI), quadratic effect of $\mathrm{pDMI}(\mathrm{pDMI} \times \mathrm{pDMI})$, and Trt by quadratic effect of $\mathrm{pDMI}($ Trt $\times \mathrm{pDMI} \times \mathrm{pDMI})$.

${ }^{2}$ Nonsignificant, with $P>0.20$; term was removed from the statistical model. 

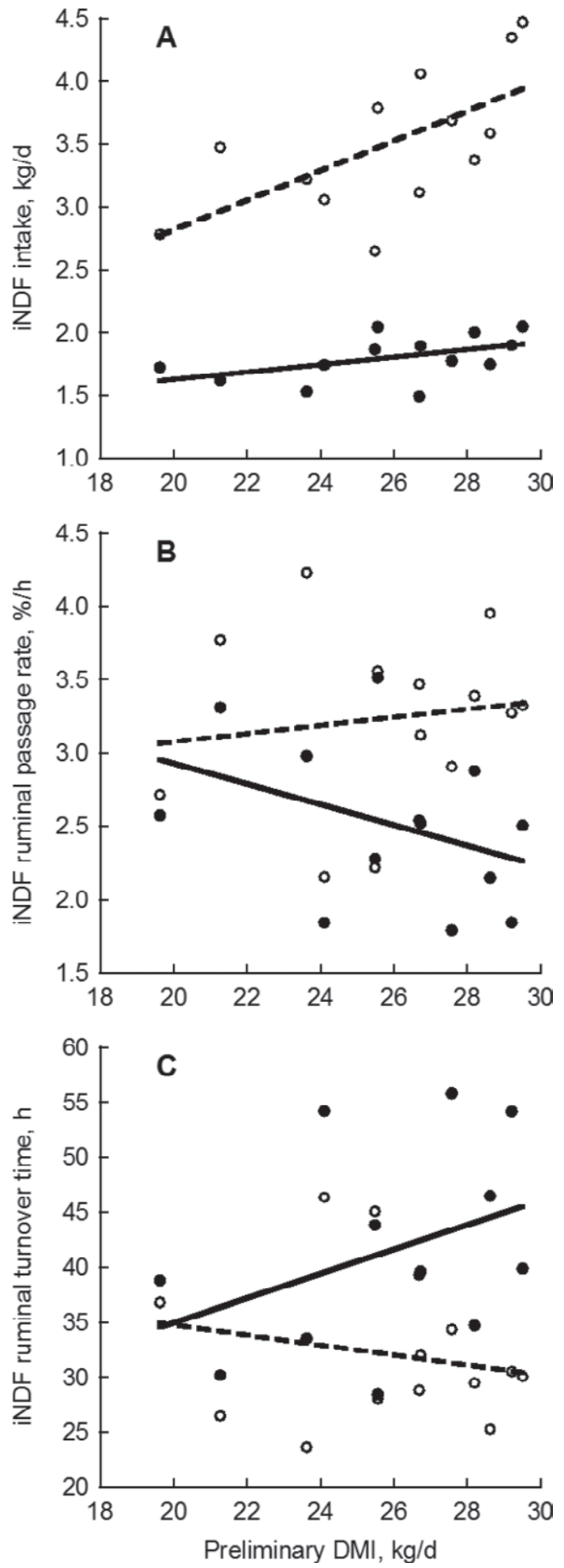

Figure 1. Interaction of alfalfa (open circles, dashed line) and orchardgrass (closed circles, solid line) with preliminary DMI for indigestible NDF (iNDF) A) intake (interaction: $P=0.05$; alfalfa: $P$ $=0.02, \mathrm{R}^{2}=0.41$; orchardgrass: $\left.P=0.09, \mathrm{R}^{2}=0.24\right), \mathrm{B}$ ) ruminal passage rate (interaction: $P=0.09$; alfalfa: $P=0.66, \mathrm{R}^{2}=0.02$; orchardgrass: $P=0.19, \mathrm{R}^{2}=0.15$ ), and $\mathrm{C}$ ) ruminal turnover time (interaction: $P=0.06$; alfalfa: $P=0.52, \mathrm{R}^{2}=0.04$; orchardgrass: $P$ $\left.=0.21, \mathrm{R}^{2}=0.14\right)$. The preliminary DMI on the $\mathrm{x}$-axes are the mean DMI of individual cows during the final $4 \mathrm{~d}$ of the preliminary period when all cows were fed a common diet. The best-fit lines are drawn to demonstrate the significant interaction even if the individual relationships are not significant.
AL increased the rumen pool size of iNDF compared with OG (4.62 vs. $3.11 \mathrm{~kg}, P<0.001)$ because of the greater intake of iNDF. The AL diet decreased rumen pools of pdNDF $(1.55$ vs. $3.54 \mathrm{~kg}, P<0.001)$, OM (9.58 vs. $11.2 \mathrm{~kg}, P=0.002)$, and $\mathrm{DM}(10.6$ vs. $12.4 \mathrm{~kg}$, $P=0.001)$ compared with OG because of lower pdNDF intake and faster rates of ruminal passage and digestion of pdNDF for AL than OG. Furthermore, AL decreased rumen digesta wet weight ( 82.7 vs. $92.4 \mathrm{~kg}, P=0.008$ ) and volume (98.5 and $108 \mathrm{~L}, P=0.01)$ compared with OG. These ruminal pool sizes indicated that OG had greater filling effects than AL. The numerically lower feed intake for OG was accompanied by greater rumen pools, suggesting rumen fill as a constraint limiting DMI for cows consuming $\mathrm{OG}$ is possible, but there was not statistically significant evidence in this experiment that ruminal distention is more likely to limit feed intake for cows with high intake compared with cows with low intake because we were unable to detect a treatment by pDMI interaction for DMI. This is in contrast to the results of Voelker Linton and Allen (2008); however, the use of cows with high feed intake levels and high dietary forage NDF concentration in this experiment may have resulted in similar physical fill effects in the rumen for cows across the range of pDMI. Although rumen fill may be the factor limiting intake for cows consuming $\mathrm{OG}$, it is not clear what mechanism is controlling intake for cows consuming AL.

Effects of treatment on ruminal kinetics affected fiber digestion in the rumen (Table 5). Although rate of ruminal digestion of pdNDF was faster for AL than OG, AL decreased pdNDF digestion in the rumen compared with OG $(2.47$ vs. $3.70 \mathrm{~kg} / \mathrm{d}, P<0.001)$ because of lower concentration of pdNDF and shorter retention time in the rumen for AL than OG. As expected, AL decreased ruminal digestibility of NDF (37.7 vs. $57.2 \%$, $P<0.001)$ compared with OG. As pDMI increased, AL maintained relatively constant ruminal fiber digestibility but OG tended to increase or increased ruminal digestibilities of pdNDF (interaction $P=0.13$; Figure $2 \mathrm{~A}$ ) and NDF (interaction $P=0.08$; Figure 2B), respectively. The AL diet decreased pdNDF flux to the duodenum (0.84 vs. $1.07 \mathrm{~kg} / \mathrm{d}, P=0.02)$ but increased NDF flux to the duodenum (4.26 vs. $2.89 \mathrm{~kg} / \mathrm{d}, P<$ 0.001) compared with OG. As a result of increasing pdNDF ruminal digestibility for OG with greater feed intake, pdNDF flux to the duodenum decreased for OG as pDMI increased (interaction $P=0.07$; Figure 2C) with the greatest difference between $\mathrm{AL}$ and $\mathrm{OG}$ for cows with low pDMI. Flux of NDF to the duodenum increased for $\mathrm{AL}$ as $\mathrm{pDMI}$ increased (interaction $P=$ 0.001; Figure 2D), with the largest difference between treatments for cows with high pDMI, which is related 
Table 6. Rumen kinetics of cows fed treatment diets containing either alfalfa (AL) or orchardgrass (OG) silage as the sole source of forage

\begin{tabular}{|c|c|c|c|c|c|c|c|c|c|}
\hline Item & \multicolumn{2}{|c|}{ Treatment LSM } & $\mathrm{SE}$ & \multicolumn{6}{|c|}{$P$-value ${ }^{1}$} \\
\hline DM & 9.76 & 8.06 & 0.41 & $<0.001$ & $\mathrm{NS}^{2}$ & NS & NS & NS & NS \\
\hline $\mathrm{OM}$ & 10.0 & 8.15 & 0.43 & $<0.001$ & NS & NS & NS & NS & NS \\
\hline $\mathrm{NDF}$ & 4.80 & 4.35 & 0.23 & 0.02 & NS & NS & NS & NS & NS \\
\hline \multicolumn{10}{|l|}{ Ruminal turnover time, $\mathrm{h}$} \\
\hline DM & 10.5 & 12.8 & 0.6 & $<0.001$ & NS & NS & NS & NS & NS \\
\hline $\mathrm{OM}$ & 10.2 & 12.7 & 0.6 & $<0.001$ & NS & NS & NS & NS & NS \\
\hline $\mathrm{NDF}$ & 21.4 & 23.9 & 1.2 & 0.01 & NS & NS & NS & NS & NS \\
\hline pdNDF & 10.9 & 17.4 & 0.9 & $<0.001$ & NS & NS & NS & NS & NS \\
\hline $\mathrm{iNDF}^{4}$ & 32.0 & 41.6 & 2.2 & $<0.001$ & NS & 0.64 & 0.06 & NS & NS \\
\hline Starch & 1.82 & 2.59 & 0.16 & 0.003 & NS & NS & NS & NS & NS \\
\hline pdNDF & 7.27 & 4.74 & 0.43 & $<0.001$ & NS & NS & NS & NS & NS \\
\hline Starch & 45.7 & 29.4 & 2.5 & 0.001 & NS & NS & NS & NS & NS \\
\hline
\end{tabular}

${ }^{1} P$-values for treatment $($ Trt $)$, Trt by period interaction $($ Trt $\times$ period), preliminary DMI $(\mathrm{pDMI})$, Trt by pDMI interaction $($ Trt $\times$ pDMI), quadratic effect of pDMI $(\mathrm{pDMI} \times \mathrm{pDMI})$, and Trt by quadratic effect of pDMI $($ Trt $\times \mathrm{pDMI} \times \mathrm{pDMI})$.

${ }^{2}$ Nonsignificant, with $P>0.20$; term was removed from the statistical model. ${ }^{3}$ pdNDF $=$ potentially digestible NDF.

${ }^{4} \mathrm{iNDF}=$ indigestible NDF.

to the greater increase in iNDF intake for $\mathrm{AL}$ as $\mathrm{pDMI}$ increased (Figure 1A).

Similar to pdNDF digestion in the rumen, AL decreased total-tract digestion of pdNDF compared with OG $(2.47$ vs. $3.14 \mathrm{~kg} / \mathrm{d}, P<0.001)$. Despite greater ruminal digestion of pdNDF for $\mathrm{OG}$, AL increased totaltract digestibility of pdNDF compared with OG (72.0 vs. $64.7 \%, P=0.02)$. The AL diet decreased total-tract digestibility of NDF compared with OG (35.5 vs. $47.1 \%$, $P<0.001$ ) because of the higher concentration of iNDF for AL than OG. Total-tract digestibilities of NDF (and pdNDF) are lower than ruminal digestibility because negative postruminal digestibilities were calculated for NDF (and pdNDF) in the present experiment. This is because of a net gain of fiber from the duodenum to the feces, which has previously been reported with both the gutter-type $\mathrm{T}$ duodenal cannula (Huhtanen and Jaakkola, 1993; Poore et al., 1993), which is the type used in this study, and the closed T-type duodenal cannula (Stensig and Robinson, 1997). Underestima-

Table 7. Rumen pools of cows fed treatment diets containing either alfalfa (AL) or orchardgrass (OG) silage as the sole source of forage

\begin{tabular}{|c|c|c|c|c|c|c|c|c|c|}
\hline Item & \multicolumn{2}{|c|}{ Treatment LSM } & $\mathrm{SE}$ & \multicolumn{6}{|c|}{$P$-value ${ }^{1}$} \\
\hline Volume, L & 98.5 & 108 & 3.6 & 0.01 & NS & 0.50 & 0.16 & NS & NS \\
\hline Density, $\mathrm{kg} / \mathrm{L}$ & 0.84 & 0.86 & 0.01 & 0.44 & 0.04 & 0.008 & 0.11 & NS & NS \\
\hline \multicolumn{10}{|l|}{ Rumen pool, $\mathrm{kg}$} \\
\hline NDF & 6.19 & 6.67 & 0.38 & 0.06 & NS & NS & NS & NS & NS \\
\hline $\operatorname{pdNDF}^{3}$ & 1.55 & 3.54 & 0.20 & $<0.001$ & 0.14 & NS & NS & NS & NS \\
\hline $\mathrm{iNDF}^{4}$ & 4.62 & 3.11 & 0.21 & $<0.001$ & NS & 0.12 & NS & NS & NS \\
\hline Starch & 0.52 & 0.78 & 0.06 & 0.002 & NS & NS & NS & NS & NS \\
\hline
\end{tabular}

${ }^{1} P$-values for treatment $($ Trt $)$, Trt by period interaction $($ Trt $\times$ period), preliminary DMI $(\mathrm{pDMI})$, Trt by pDMI interaction $($ Trt $\times$ pDMI), quadratic effect of pDMI $(\mathrm{pDMI} \times \mathrm{pDMI})$, and Trt by quadratic effect of $\mathrm{pDMI}($ Trt $\times \mathrm{pDMI} \times \mathrm{pDMI})$.

${ }^{2}$ Nonsignificant, with $P>0.20$; term was removed from the statistical model. ${ }^{3}$ pdNDF $=$ potentially digestible NDF.

${ }^{4} \mathrm{iNDF}=$ indigestible NDF. 

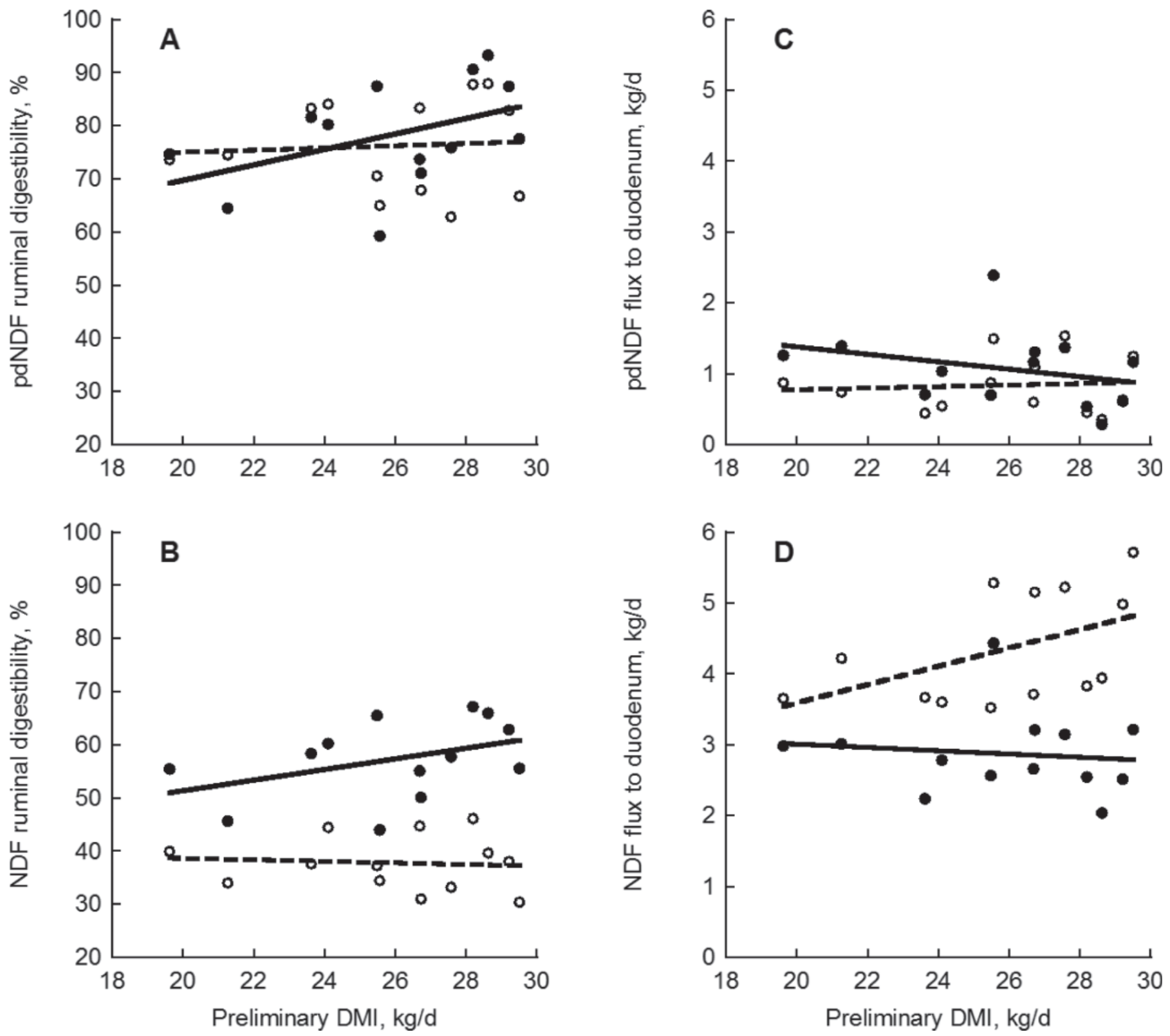

Figure 2. Interaction of alfalfa (open circles, dashed line) and orchardgrass (closed circles, solid line) with preliminary DMI for A) ruminal digestibility of potentially digestible NDF (pdNDF; interaction: $P=0.13$; alfalfa: $P=0.82, \mathrm{R}^{2}=0.005$; orchardgrass: $P=0.13, \mathrm{R}^{2}=0.20$ ), $\mathrm{B}$ ) ruminal digestibility of NDF (interaction: $P=0.08$; alfalfa: $P=0.78, \mathrm{R}^{2}=0.007$; orchardgrass: $P=0.16, \mathrm{R}^{2}=0.17$ ), C) pdNDF flux to duodenum (interaction: $P=0.07$; alfalfa: $P=0.79, \mathrm{R}^{2}=0.007$; orchardgrass: $P=0.32, \mathrm{R}^{2}=0.09$ ), and $\mathrm{D}$ ) NDF flux to duodenum (interaction: $P=$ 0.001; alfalfa: $P=0.09, \mathrm{R}^{2}=0.24$; orchardgrass: $P=0.70, \mathrm{R}^{2}=0.01$ ). The preliminary DMI on the x-axes are the mean DMI of individual cows during the final $4 \mathrm{~d}$ of the preliminary period when all cows were fed a common diet. The best-fit lines are drawn to demonstrate the significant interaction even if the individual relationships are not significant.

tion of duodenal NDF flow or duodenal iNDF:NDF ratio using iNDF as a marker creates inaccuracies of estimated flow of duodenal fiber and postruminal digestibility. These errors may be related to unrepresentative digesta sampling due to differential separation of fluid and particles relative to the true material flowing out of the duodenum or analytical problems in fiber determination of duodenal samples, possibly because a component in the duodenal digesta interferes with the analysis. While not all absolute values are biologically reasonable, relative comparisons between treatments within the same experiment are useful. We think it is unlikely that errors are biased in relation to level of intake because of opposite responses to treatment as 
pDMI increases (e.g., passage rate of iNDF; Figure 1B) and because we have previously observed significant and expected relationships between variables measured with the pool and flux method and variables that have been measured independently (e.g., rate of digestion of pdNDF and ruminal pH; Oba and Allen, 2003b).

Different concentrate levels in the diets were necessary to account for changes in chemical composition of forages and maintain the same concentration of forage NDF in the diets. The AL diet decreased starch intake $(6.82$ vs. $7.16 \mathrm{~kg} / \mathrm{d}, P=0.05$; Table 8$)$ and increased starch ruminal digestion rate (45.7 vs. $29.4 \%, P=$ 0.001; Table 6) compared with OG. This is consistent with the greater rate of ruminal turnover of starch $(59.3$ vs. $42.1 \% / \mathrm{h}, P=0.005$; Table 6$)$ and smaller rumen pool of starch (0.52 vs. $0.78 \mathrm{~kg}, P=0.002$; Table 7) for AL than OG. Although there was no difference in the amount of starch digested in the rumen per day, AL increased true ruminal starch digestibility (80.4 vs. $74.7 \%, P=0.03)$ and decreased starch flux to the duodenum (1.55 vs. $2.02 \mathrm{~kg} / \mathrm{d}, P=0.04$; Table 8) compared with $O G$ because of lower intake and faster digestion rate of starch for AL than OG. The AL diet tended to decrease postruminal starch digestibility (19.6 vs. $24.2 \%, P=0.07)$ and decreased starch postruminally digested (1.33 vs. $1.74 \mathrm{~kg} / \mathrm{d}, P=0.05)$ compared with OG (Table 8). In the total tract, AL increased starch digestibility (97.0 vs. $95.6 \%, P=0.04$ ) but tended to decrease starch digestion ( 6.60 vs. $6.89 \mathrm{~kg} / \mathrm{d}, P=0.08)$ compared with OG (Table 8).

The mechanism by which AL increased ruminal starch digestion is unclear. It is possible that alfalfa promotes greater numbers or activity of starch-digesting bacteria in the rumen than orchardgrass. Because some starchdigesting bacteria (e.g., Streptococcus bovis) also have high proteolytic activity (Russell et al., 1981), resulting in deamination of AA and production of ammonia, they might have contributed to the higher ruminal concentrations of isobutyrate (1.71 vs. $1.17 \mathrm{mM}, P<0.001)$, isovalerate (2.32 vs. $1.81 \mathrm{~m} M, P=0.01)$, branchedchain VFA (4.03 vs. 2.97, $P=0.001$; Table 9 ), and ammonia (20.0 vs. $13.5 \mathrm{mg} / \mathrm{dL}, P<0.001$; Table 10 ) for AL compared with OG. Alfalfa silage, which had higher ammonia concentration than orchardgrass silage (Table 2), is another possible source for the increased ruminal ammonia observed in cows fed AL.

The AL diet increased ruminal $\mathrm{pH}$ (6.07 vs. 5.90, $P$ $=0.001$; Table 9) compared with OG. Although we expected AL to have higher $\mathrm{pH}$ than OG because of lower starch intake, there was no difference in ruminal digestion of starch or $\mathrm{OM}(\mathrm{kg} / \mathrm{d}$; Tables 8 and 11 , respectively), and AL tended to increase total VFA concentration (149 vs. $146 \mathrm{~m} M, P=0.09$; Table 9). Additionally, rumen digesta mass was less for AL than OG (Table 7), potentially decreasing buffer capacity, and ruminating time per day was not different between AL and OG (Table 12), suggesting similar buffering through saliva secretion. The $\mathrm{pH}$ difference observed was likely because the buffering capacity of the rumen contents were greater for AL than OG; buffer capacity of legumes is greater than grasses (Jasaitis et al., 1987).

Although there was no effect of treatment on ruminating time per day, forage family affected eating time per day (Table 12). The AL diet tended to increase eating time per day (295 vs. $271 \mathrm{~min} / \mathrm{d}, P=0.10$ ) by increasing the number of meal bouts per day (10.3 vs.

Table 8. Starch digestion of cows fed treatment diets containing either alfalfa (AL) or orchardgrass (OG) silage as the sole source of forage

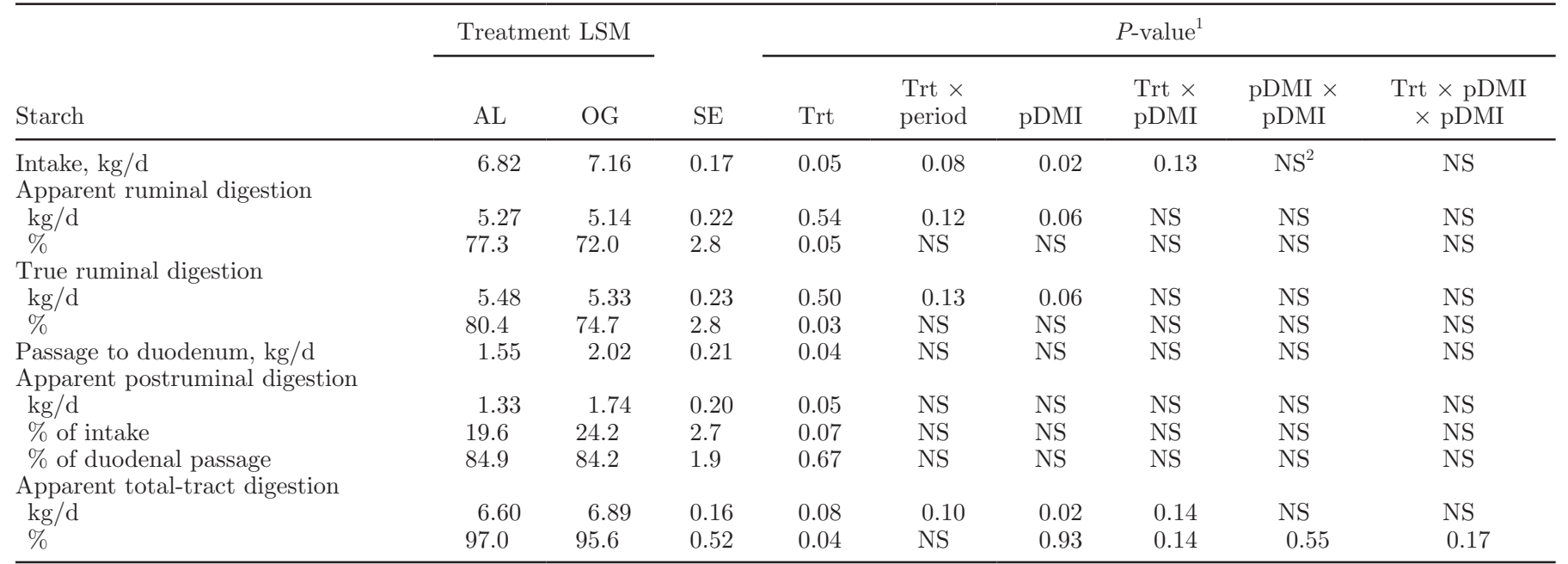

${ }^{1} P$-values for treatment (Trt), Trt by period interaction $($ Trt $\times$ period), preliminary DMI $(\mathrm{pDMI})$, Trt by pDMI interaction $($ Trt $\times$ pDMI), quadratic effect of $\mathrm{pDMI}(\mathrm{pDMI} \times \mathrm{pDMI})$, and Trt by quadratic effect of $\mathrm{pDMI}($ Trt $\times \mathrm{pDMI} \times \mathrm{pDMI})$.

${ }^{2}$ Nonsignificant, with $P>0.20$; term was removed from the statistical model. 
Table 9. Ruminal VFA concentrations and $\mathrm{pH}$ of cows fed treatment diets containing either alfalfa (AL) or orchardgrass (OG) silage as the sole source of forage

\begin{tabular}{|c|c|c|c|c|c|c|c|c|c|}
\hline Item & \multicolumn{2}{|c|}{ Treatment LSM } & $\mathrm{SE}$ & \multicolumn{6}{|c|}{$P$-value ${ }^{1}$} \\
\hline Acetate & 90.8 & 91.5 & 1.2 & 0.59 & NS & NS & NS & NS & NS \\
\hline Propionate & 31.5 & 29.0 & 2.2 & 0.05 & NS & 0.93 & 0.15 & 0.22 & 0.03 \\
\hline Butyrate & 18.6 & 17.9 & 1.0 & 0.20 & NS & 0.78 & 0.58 & 0.96 & 0.16 \\
\hline Valerate & 2.52 & 1.65 & 0.14 & $<0.001$ & NS & 0.68 & NS & 0.18 & NS \\
\hline Isovalerate & 2.32 & 1.81 & 0.11 & 0.01 & NS & NS & NS & NS & NS \\
\hline Branched-chain VFA & 4.03 & 2.97 & 0.15 & 0.001 & NS & NS & NS & NS & NS \\
\hline Acetate:propionate & 2.92 & 3.19 & 0.16 & 0.03 & NS & 0.92 & 0.25 & 0.19 & 0.07 \\
\hline Ruminal pH & 6.07 & 5.90 & 0.05 & 0.001 & NS & NS & NS & NS & NS \\
\hline
\end{tabular}

${ }^{1} P$-values for treatment $($ Trt), Trt by period interaction $($ Trt $\times$ period), preliminary DMI (pDMI), Trt by pDMI interaction $($ Trt $\times$ pDMI), quadratic effect of pDMI $(\mathrm{pDMI} \times \mathrm{pDMI})$, and Trt by quadratic effect of pDMI $($ Trt $\times \mathrm{pDMI} \times \mathrm{pDMI})$.

${ }^{2}$ Nonsignificant, with $P>0.20$; term was removed from the statistical model.

8.96 meals $/ \mathrm{d}, P=0.03$, with the greatest difference for cows with high pDMI (interaction $P=0.10$; Figure $3 \mathrm{~A}$ ), and tending to decrease the interval between meals (131 vs. $152 \mathrm{~min}, P=0.09$ ). As pDMI increased, AL tended to increase the number of rumination bouts per day (interaction $P=0.13$; Figure $3 \mathrm{~B}$ ) and decrease the interval between rumination bouts (interaction $P=$ 0.14; Figure 3C), whereas the reverse was observed for
OG. The AL diet decreased ruminating time per unit of forage NDF consumed (78.4 vs. $84.7 \mathrm{~min} / \mathrm{kg}$ forage NDF, $P=0.02$; Table 12) compared with OG. This indicated that alfalfa provided less physically effective fiber than orchardgrass.

As previously mentioned, AL increased and $\mathrm{OG}$ decreased BW (Table 4). These BW changes are consistent with numerically higher DMI for AL but similar

Table 10. Nitrogen metabolism of cows fed treatment diets containing either alfalfa (AL) or orchardgrass (OG) silage as the sole source of forage

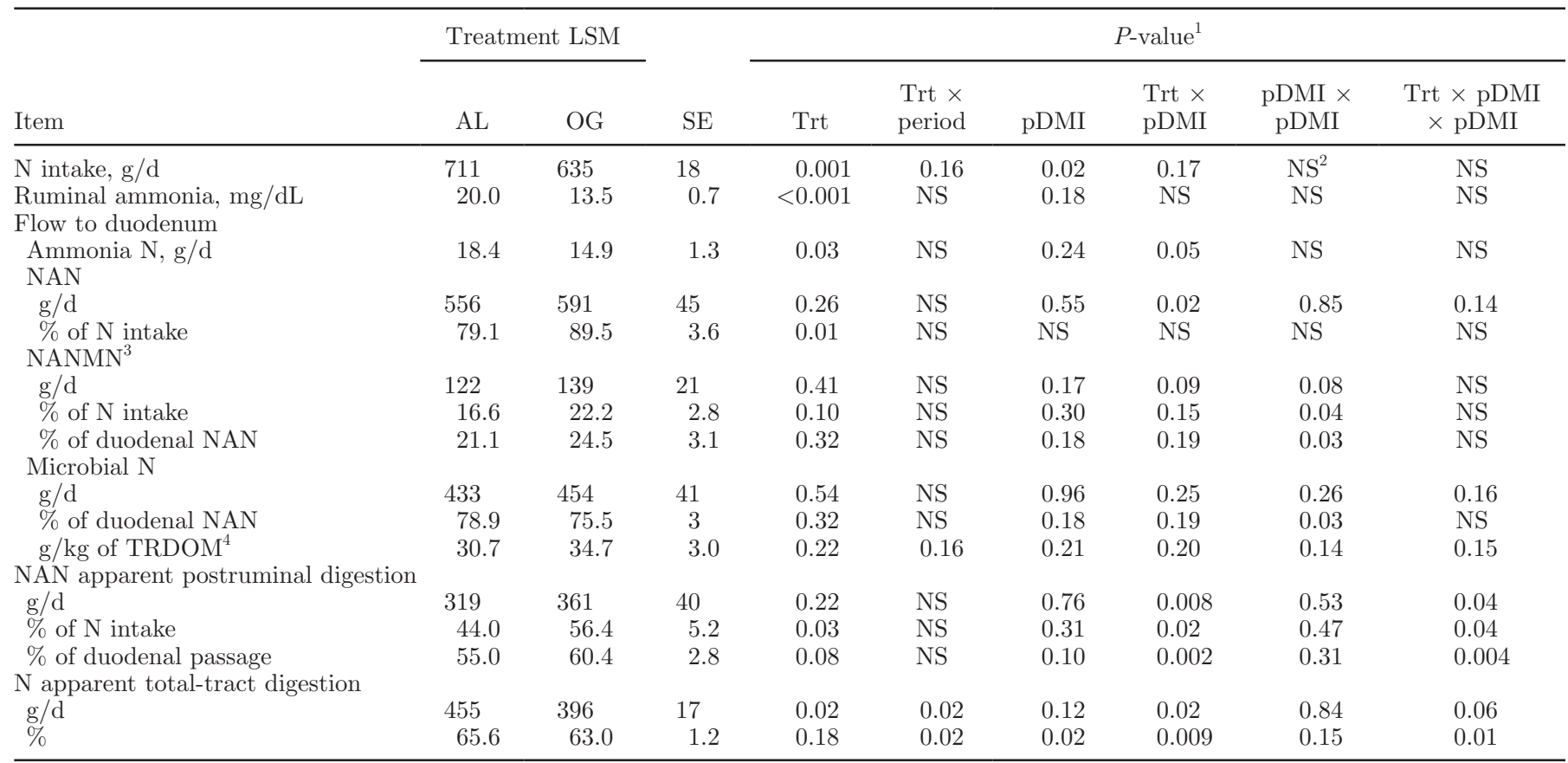

${ }^{1} P$-values for treatment $($ Trt $)$, Trt by period interaction $($ Trt $\times$ period), preliminary DMI $(\mathrm{pDMI})$, Trt by pDMI interaction $($ Trt $\times$ pDMI $)$, quadratic effect of $\mathrm{pDMI}(\mathrm{pDMI} \times \mathrm{pDMI})$, and Trt by quadratic effect of $\mathrm{pDMI}($ Trt $\times \mathrm{pDMI} \times \mathrm{pDMI})$.

${ }^{2}$ Nonsignificant, with $P>0.20$; term was removed from the statistical model. ${ }^{3} \mathrm{NANMN}=$ nonammonia, nonmicrobial nitrogen.

${ }^{4} \mathrm{TRDOM}=$ true ruminally digested OM. 
Table 11. Dry matter and OM digestion of cows fed treatment diets containing either alfalfa (AL) or orchardgrass (OG) silage as the sole source of forage

\begin{tabular}{|c|c|c|c|c|c|c|c|c|c|}
\hline Item & \multicolumn{2}{|c|}{ Treatment LSM } & $\mathrm{SE}$ & \multicolumn{6}{|c|}{$P$-value ${ }^{1}$} \\
\hline \multicolumn{10}{|l|}{$\mathrm{DM}$} \\
\hline Intake, $\mathrm{kg} / \mathrm{d}$ & 24.2 & 23.2 & 0.6 & 0.13 & 0.09 & 0.02 & $\mathrm{NS}^{2}$ & NS & NS \\
\hline \multicolumn{10}{|l|}{ Apparent total-tract digestion } \\
\hline $\mathrm{kg} / \mathrm{d}$ & 15.7 & 15.0 & 0.4 & 0.20 & 0.003 & 0.03 & 0.13 & NS & NS \\
\hline Intake, $\mathrm{kg} / \mathrm{d}$ & 22.5 & 21.2 & 0.6 & 0.04 & 0.08 & 0.02 & NS & NS & NS \\
\hline \multicolumn{10}{|l|}{ Apparent ruminal digestion } \\
\hline $\mathrm{kg} / \mathrm{d}$ & 9.49 & 9.19 & 0.6 & 0.64 & 0.006 & 0.01 & NS & 0.09 & NS \\
\hline$\%$ & 44.9 & 42.6 & 2.8 & 0.44 & 0.09 & 0.27 & 0.06 & 0.28 & 0.12 \\
\hline \multicolumn{10}{|l|}{ True ruminal digestion } \\
\hline $\mathrm{kg} / \mathrm{d}$ & 14.4 & 13.8 & 0.5 & 0.35 & 0.01 & 0.009 & NS & NS & NS \\
\hline$\%$ & 64.1 & 65.1 & 1.5 & 0.55 & 0.15 & 0.43 & 0.09 & NS & NS \\
\hline $\mathrm{kg} / \mathrm{d}$ & 14.8 & 14.0 & 0.4 & 0.12 & 0.004 & 0.03 & 0.12 & NS & NS \\
\hline$\%$ & 65.5 & 68.2 & 1.1 & 0.10 & 0.009 & 0.06 & 0.05 & 0.16 & 0.08 \\
\hline
\end{tabular}

${ }^{1} P$-values for treatment $($ Trt $)$, Trt by period interaction (Trt $\times$ period), preliminary DMI $(\mathrm{pDMI})$, Trt by pDMI interaction $($ Trt $\times \mathrm{pDMI})$, quadratic effect of $\mathrm{pDMI}(\mathrm{pDMI} \times \mathrm{pDMI})$, and Trt by quadratic effect of $\mathrm{pDMI}($ Trt $\times \mathrm{pDMI} \times \mathrm{pDMI})$.

${ }^{2}$ Nonsignificant, with $P>0.20$; term was removed from the statistical model.

FCM yield as OG; however, this occurred despite the tendency for lower plasma insulin concentrations for AL compared with OG (10.4 vs. $12.3 \mu \mathrm{IU}, P=0.10$; Table 13). As pDMI increased, plasma concentrations of glucose $(P=0.004$; Figure $4 \mathrm{~A})$, glucagon $(P=0.02$; Figure $4 \mathrm{~B})$, and insulin $(P=0.02$; Figure $4 \mathrm{C})$ decreased independent of treatment.

\section{Effects of pDMI on Ruminal Passage Rates}

Experimental data on rates of passage from the rumen, particularly for individual nutrient fractions, are scarce. Given the impact of passage on ruminal digestibility and pool sizes and microbial growth, quantitative knowledge on rates of nutrient passage from the rumen are needed to better understand nutrient availability in ruminants and improve nutrition models. Furthermore, because passage rates from the rumen generally increase with increased intake, measurements of ruminal passage rates of nutrients over a wide range of DMI are necessary. We measured the effects of DMI on rates of passage of feed fractions from the rumen using the pool and flux method (Robinson et al., 1987).

We expected ruminal passage rates to increase with pDMI. The passage rate of iNDF was related to pDMI as previously discussed, but passage rates of pdNDF and starch were not related to pDMI, either independent of or dependent upon treatment (Table 6).

\section{Effects of Treatment and pDMI on N Flux and Microbial Efficiency}

Results for $\mathrm{N}$ metabolism are shown in Table 10. The AL diet increased $\mathrm{N}$ intake compared with OG (711 vs. $635 \mathrm{~g} / \mathrm{d}, P=0.001)$ with alfalfa silage as the primary source of $\mathrm{N}$ for AL. As previously mentioned, AL increased ruminal ammonia concentration and tended to decrease NANMN flux expressed as percent of $\mathrm{N}$ intake (16.6 vs. $22.2 \%$ of $\mathrm{N}$ intake, $P=0.10$ ) compared with OG, indicating that protein was more rapidly degraded in the rumen for AL than OG. The high MN and low RUP (NANMN - endogenous N) values obtained in this study are likely the result of more extensive degradation of $\mathrm{CP}$ of forages than databases with in situ or in vitro data suggest because rumen retention of forages is longer than values reported in the literature using rare earth markers (Krizsan et al., 2010). Ammonia $\mathrm{N}$, NANMN, and NAN fluxes from the rumen to the duodenum were related to pDMI, but the response differed by treatment. As pDMI increased, AL increased fluxes of ammonia N (interaction $P=0.05$; Figure 5A), NANMN (interaction $P=0.09$; Figure $5 \mathrm{~B}$ ), and NAN (interaction $P=0.02$; Figure $5 \mathrm{C}$ ), whereas these fluxes remained relatively constant across the range of pDMI for OG. The NANMN interaction contributed to the treatment by pDMI interaction for NAN flux because level of intake did not have an effect on MN flux. In a 
Table 12. Chewing activity of cows fed treatment diets containing either alfalfa (AL) or orchardgrass (OG) silage as the sole source of forage

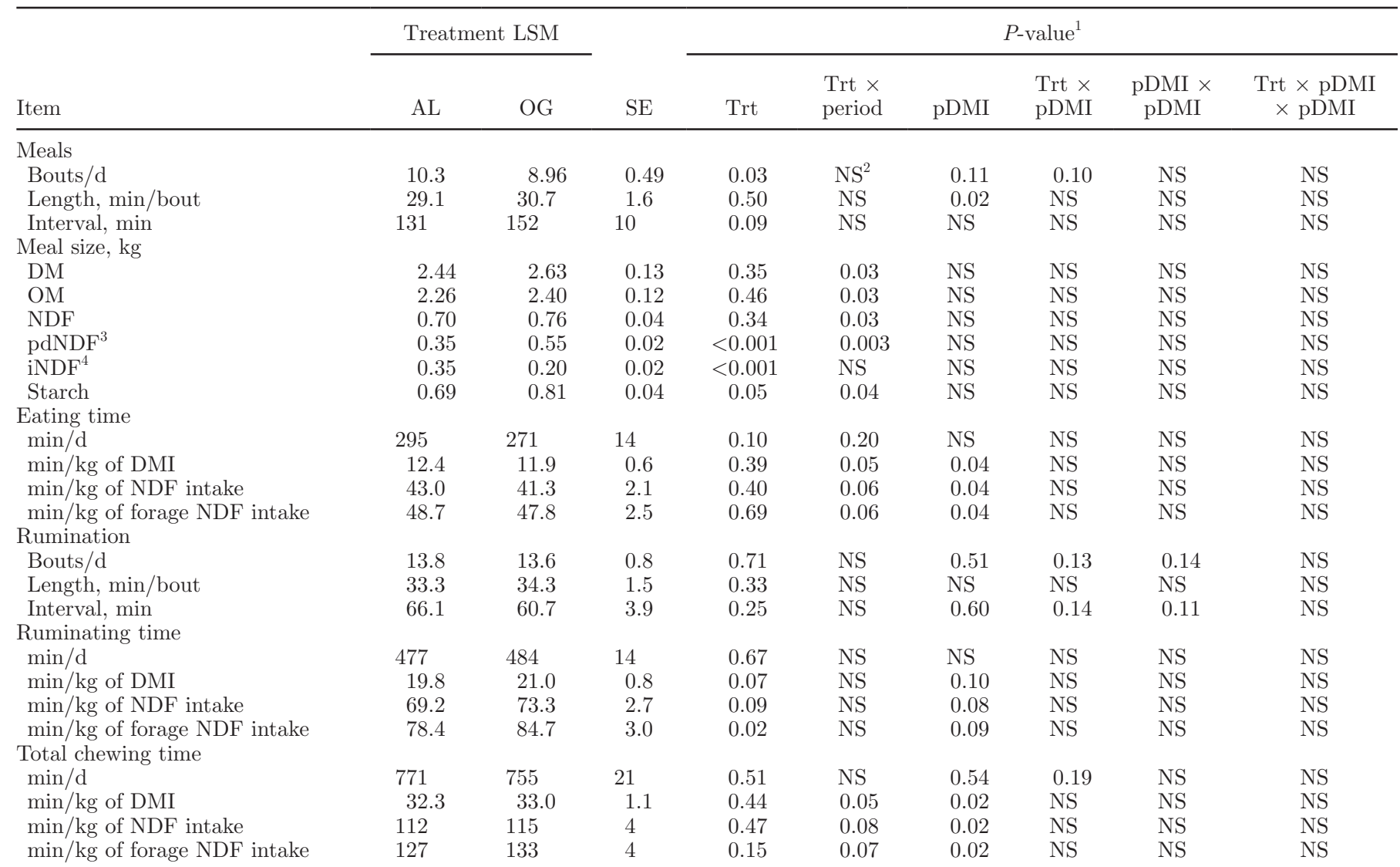

${ }^{1} P$-values for treatment (Trt), Trt by period interaction $($ Trt $\times$ period), preliminary DMI $(\mathrm{pDMI})$, Trt by pDMI interaction $($ Trt $\times$ pDMI), quadratic effect of $\mathrm{pDMI}(\mathrm{pDMI} \times \mathrm{pDMI})$, and Trt by quadratic effect of $\mathrm{pDMI}($ Trt $\times \mathrm{pDMI} \times \mathrm{pDMI})$.

${ }^{2}$ Nonsignificant, with $P>0.20$; term was removed from the statistical model. ${ }^{3}$ pdNDF $=$ potentially digestible NDF.

${ }^{4} \mathrm{iNDF}=$ indigestible $\mathrm{NDF}$.

review by Clark et al. (1992), positive linear relationships between OM intake and fluxes of NAN, NANMN, and $\mathrm{MN}$ were reported as $\mathrm{OM}$ intake increased over a very wide range (3 to $23 \mathrm{~kg} / \mathrm{d})$. The higher $\mathrm{DMI}$ and narrower range of DMI in the present experiment might have precluded detection of the positive relationships demonstrated by Clark et al. (1992).
Based on studies with continuous culture fermenters, increases in solid and liquid dilution rates, which might be associated with increased intake, resulted in greater microbial efficiency (Crawford et al., 1980; Shriver et al., 1986). In this experiment, efficiency of microbial protein synthesis tended to be related to pDMI (interaction $P=0.15$ ), but the response varied by treatment.

Table 13. Plasma metabolites of cows fed treatment diets containing either alfalfa (AL) or orchardgrass (OG) silage as the sole source of forage

\begin{tabular}{|c|c|c|c|c|c|c|c|c|c|}
\hline \multirow[b]{2}{*}{ Item } & \multicolumn{2}{|c|}{ Treatment LSM } & \multirow[b]{2}{*}{ SE } & \multicolumn{6}{|c|}{$P$-value ${ }^{1}$} \\
\hline & $\mathrm{AL}$ & OG & & Trt & $\begin{array}{l}\text { Trt } \times \\
\text { period }\end{array}$ & $\mathrm{pDMI}$ & $\begin{array}{l}\text { Trt } \times \\
\text { pDMI }\end{array}$ & $\begin{array}{c}\mathrm{pDMI} \times \\
\mathrm{pDMI}\end{array}$ & $\begin{array}{c}\text { Trt } \times \text { pDMI } \\
\times \text { pDMI }\end{array}$ \\
\hline Glucagon, pg/mL & 144 & 164 & 3 & $<0.001$ & NS & 0.02 & NS & NS & NS \\
\hline Insulin, $\mu \mathrm{IU} / \mathrm{mL}$ & 10.4 & 12.3 & 1.0 & 0.10 & 0.10 & 0.02 & NS & NS & NS \\
\hline
\end{tabular}

${ }^{1} P$-values for treatment (Trt), Trt by period interaction (Trt $\times$ period), preliminary DMI (pDMI), Trt by pDMI interaction $($ Trt $\times$ pDMI), quadratic effect of $\mathrm{pDMI}(\mathrm{pDMI} \times \mathrm{pDMI})$, and Trt by quadratic effect of $\mathrm{pDMI}($ Trt $\times \mathrm{pDMI} \times \mathrm{pDMI})$.

${ }^{2}$ Nonsignificant, with $P>0.20$; term was removed from the statistical model. 

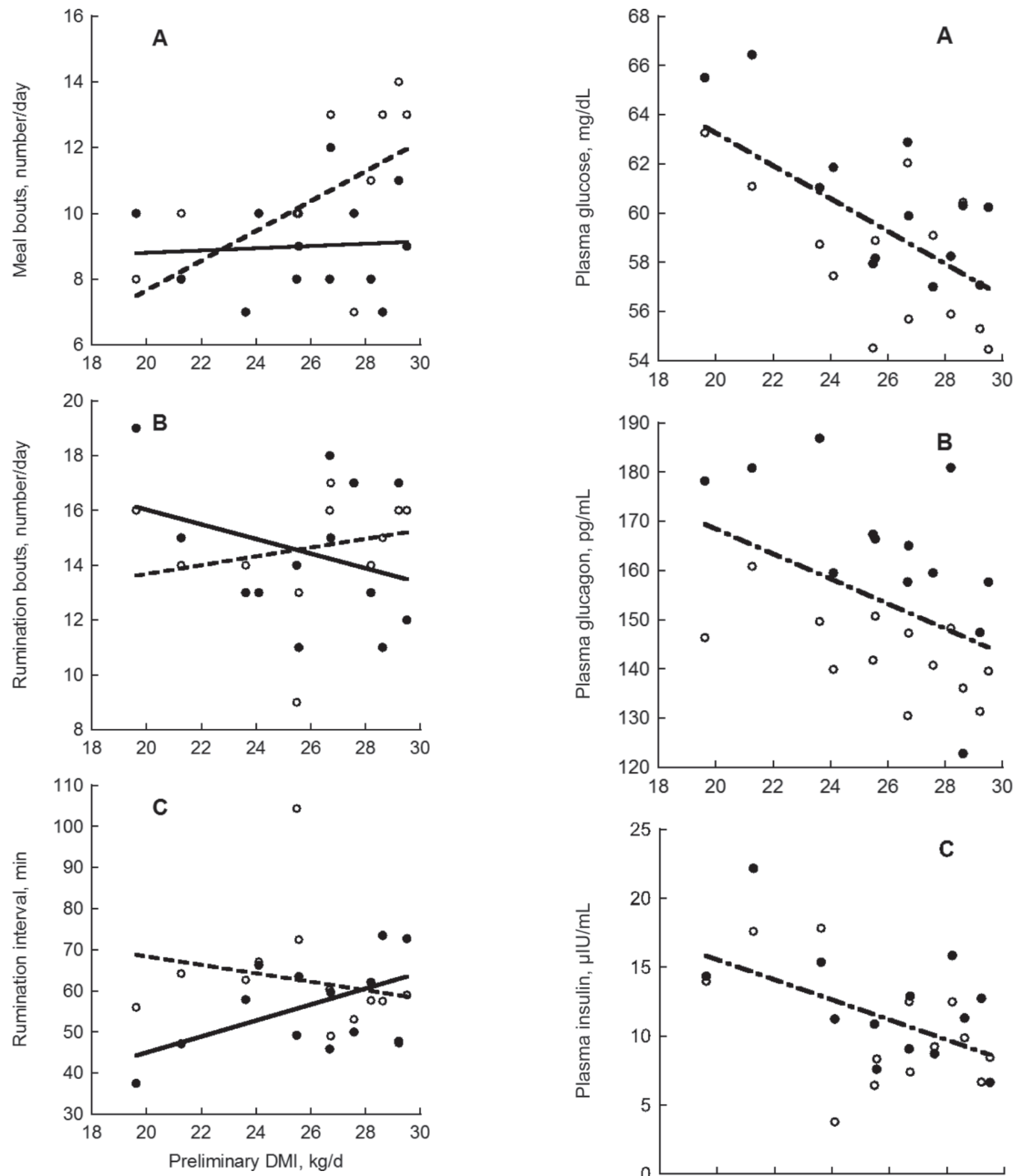

Figure 3. Interaction of alfalfa (open circles, dashed line) and orchardgrass (closed circles, solid line) with preliminary DMI for A) meal bouts (interaction: $P=0.10$; alfalfa: $P=0.04, \mathrm{R}^{2}=0.33$; orchardgrass: $\left.P=0.83, \mathrm{R}^{2}=0.005\right), \mathrm{B}$ ) rumination bouts (interaction: $P=0.13$; alfalfa: $P=0.47, \mathrm{R}^{2}=0.05$; orchardgrass: $P=0.31, \mathrm{R}^{2}=$ 0.09 ), and C) rumination interval (interaction: $P=0.14$; alfalfa: $P=$ $0.48, \mathrm{R}^{2}=0.05$; orchardgrass: $\left.P=0.06, \mathrm{R}^{2}=0.28\right)$. The preliminary DMI on the $\mathrm{x}$-axes are the mean DMI of individual cows during the final $4 \mathrm{~d}$ of the preliminary period when all cows were fed a common diet. The best-fit lines are drawn to demonstrate the significant interaction even if the individual relationships are not significant.

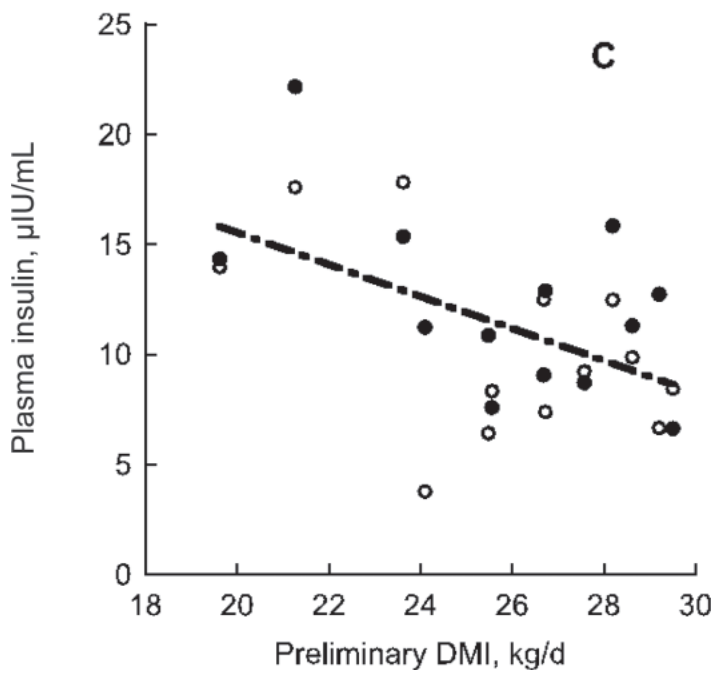

Figure 4. Relationship of alfalfa (open circles) and orchardgrass (closed circles) with preliminary DMI for concentrations of plasma A) glucose (interaction $P=0.004$; best-fit line: $P<0.001, \mathrm{R}^{2}=0.39$ ), $\mathrm{B}$ ) glucagon (interaction $P=0.02$; best-fit line: $P=0.02, \mathrm{R}^{2}=0.20$ ), and C) insulin (interaction $P=0.02$; best-fit line: $P=0.01, \mathrm{R}^{2}=0.26$ ). The preliminary DMI on the $\mathrm{x}$-axis are the mean DMI of individual cows during the final $4 \mathrm{~d}$ of the preliminary period when all cows were fed a common diet. 

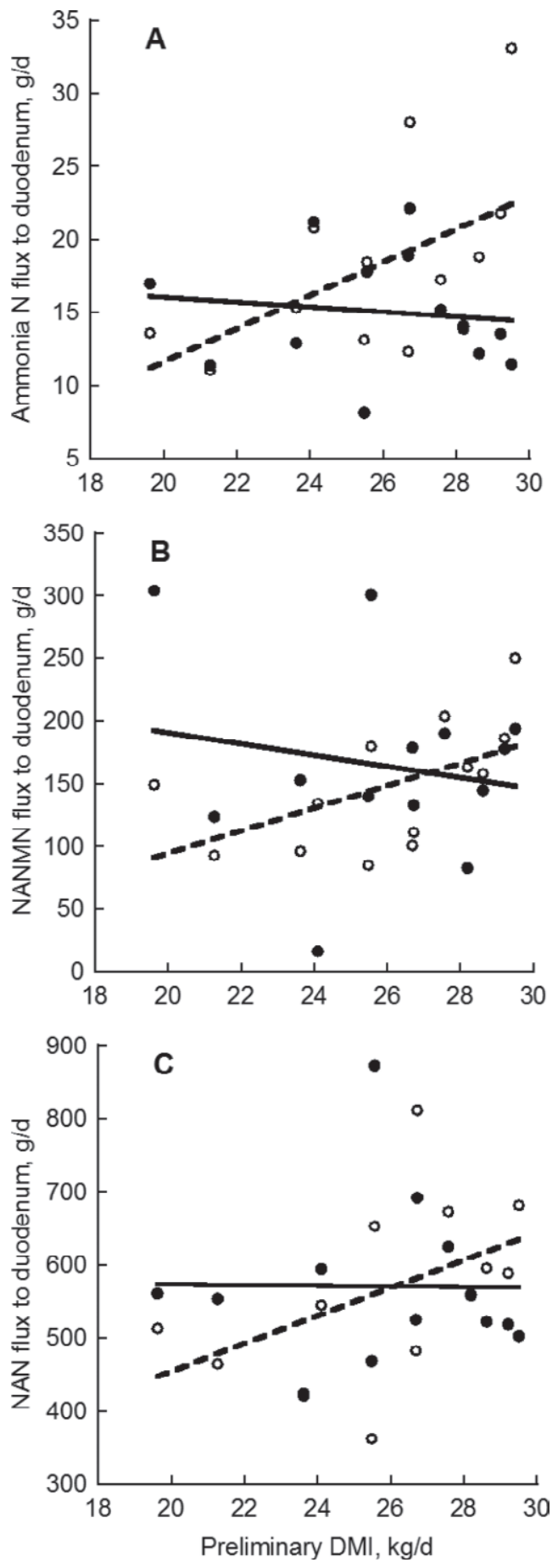

Figure 5. Interaction of alfalfa (open circles, dashed line) and orchardgrass (closed circles, solid line) with preliminary DMI for A) ammonia N (interaction: $P=0.05$; alfalfa: $P=0.06, \mathrm{R}^{2}=0.28$; orchardgrass: $\left.P=0.69, \mathrm{R}^{2}=0.01\right)$, B) nonammonia, nonmicrobial $\mathrm{N}$ (NANMN; interaction: $P=0.09$; alfalfa: $P=0.05, \mathrm{R}^{2}=0.30$; orchardgrass: $P=0.57, \mathrm{R}^{2}=0.03$ ), and $\mathrm{C}$ ) NAN (interaction: $P=0.02$; alfalfa: $P=0.10, \mathrm{R}^{2}=0.22$; orchardgrass: $\left.P=0.97, \mathrm{R}^{2}<0.001\right)$ flux to the duodenum. The preliminary DMI on the $\mathrm{x}$-axes are the mean DMI of individual cows during the final $4 \mathrm{~d}$ of the preliminary period when all cows were fed a common diet. The best-fit lines are drawn to demonstrate the significant interaction even if the individual relationships are not significant.

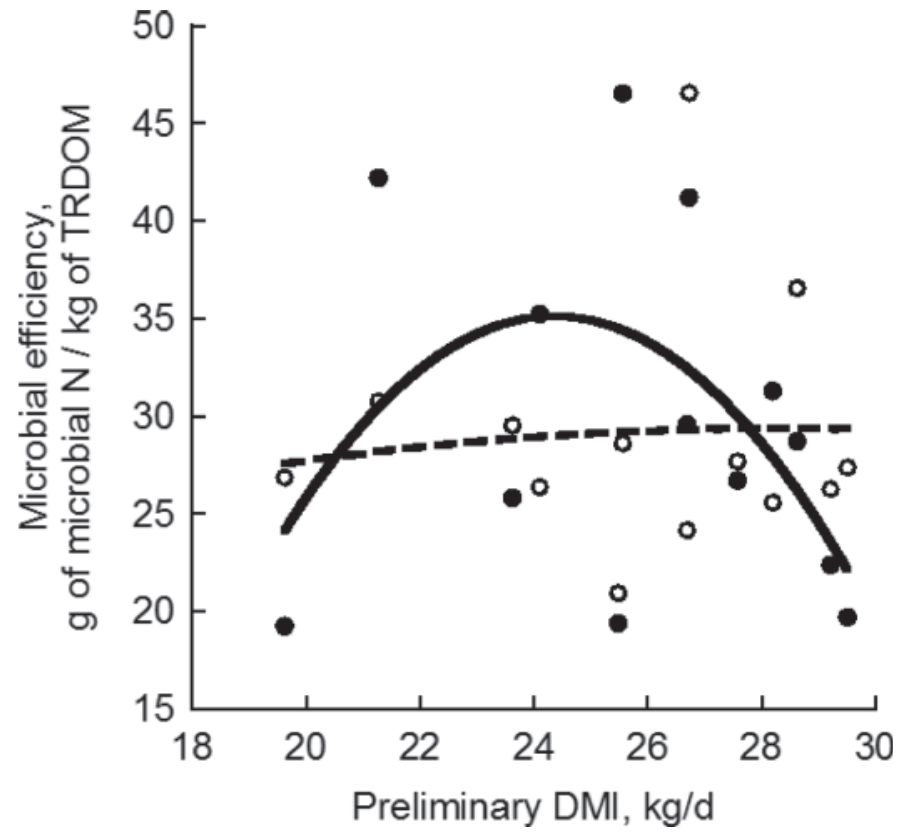

Figure 6. Interaction of alfalfa (open circles, dashed line) and orchardgrass (closed circles, solid line) with preliminary DMI for microbial efficiency, expressed as grams of microbial $\mathrm{N}$ produced per kilogram of true ruminally digested OM (TRDOM; interaction: $P=$ 0.15 quadratic; alfalfa: $P=0.96, \mathrm{R}^{2}=0.007$; orchardgrass: $P=0.23$, $\left.\mathrm{R}^{2}=0.26\right)$. The preliminary DMI on the $\mathrm{x}$-axis are the mean DMI of individual cows during the final $4 \mathrm{~d}$ of the preliminary period when all cows were fed a common diet. The best-fit lines are drawn to demonstrate the significant interaction even if the individual relationships are not significant.

Microbial efficiency remained relatively constant across the range of $\mathrm{pDMI}$ for $\mathrm{AL}$ and was affected quadratically as pDMI increased for OG (Figure 6). There was no relationship between microbial efficiency and true ruminally digested OM, which increased linearly with increasing levels of intake (Table 11) for cows consuming $\mathrm{AL}$ or $\mathrm{OG}$ (not shown), indicating that factors other than availability of energy limited efficiency of MN production and energy from OM fermentation was uncoupled from microbial growth (Russell and Cook, 1995).

Microbial $\mathrm{N}$ flux from the rumen to the duodenum increased independent of treatment as pdNDF ruminal passage rate increased $(P=0.02$; Figure $7 \mathrm{~A})$. Taylor and Allen (2005) reported a tendency for a positive correlation between MN flux and iNDF passage rate, but these relationships were not detected in the present experiment. Microbial efficiency increased as pdNDF ruminal passage rate increased for OG $(P=0.02)$ but not $\mathrm{AL}(P=0.15$; Figure $7 \mathrm{~B})$. This response indicates that energy from ruminal fermentation of $O G$ was more efficiently utilized for microbial growth as passage rates for pdNDF increased. Others have reported that microbial efficiency was positively related to passage 

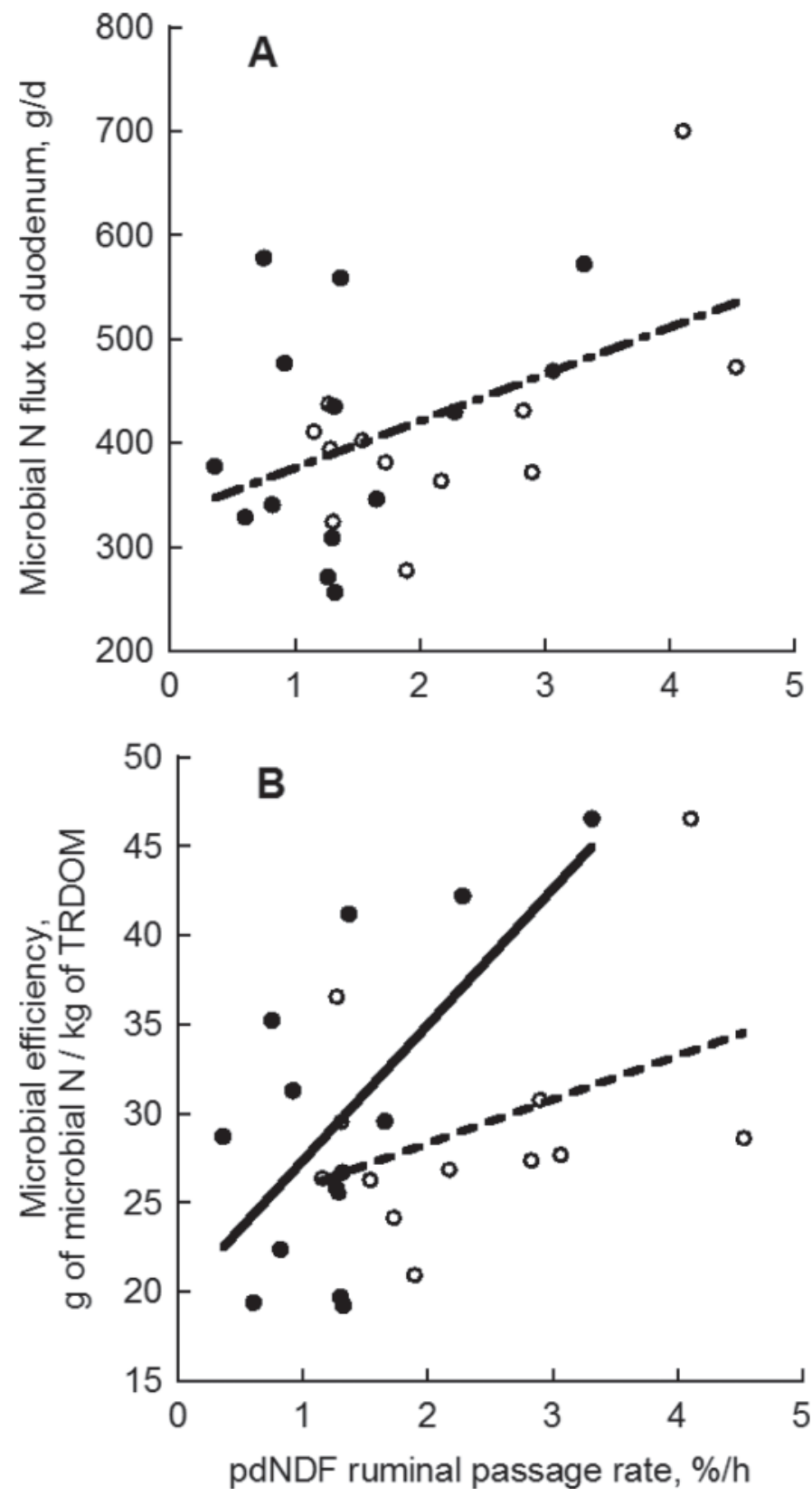

Figure 7. A) Relationship between potentially digestible NDF (pdNDF) ruminal passage rate and microbial $\mathrm{N}$ flux to duodenum $(P$ $=0.02, \mathrm{R}^{2}=0.21$ ). B) Relationship between pdNDF ruminal passage rate and microbial efficiency for alfalfa $\left(P=0.15, \mathrm{R}^{2}=0.18\right)$ and orchardgrass [microbial efficiency, g of microbial N/kg of true ruminally digested OM $($ TRDOM $)=19.8+7.60 \times$ pdNDF ruminal passage rate, $\left.\% / \mathrm{h} ; P=0.02, \mathrm{R}^{2}=0.42\right]$. Open circles and dashed line denote alfalfa, and closed circles and solid line denote orchardgrass.

rates of particulate matter from the rumen including pdNDF (Voelker and Allen, 2003) and starch (Oba and Allen, 2003c; Voelker and Allen, 2003; Taylor and Allen, 2005) in experiments evaluating carbohydrate source, concentration, and fermentability of diets in dairy cattle. The greater passage rates of particulate digesta likely decrease microbial lysis and turnover in the rumen because microbial organisms flow from the rumen primarily attached to feed particles, resulting in improved efficiency.

\section{CONCLUSIONS}

The AL diet increased ruminal $\mathrm{pH}$, rates of digestion and passage of pdNDF, and rate of digestion of starch compared with OG. The AL diet decreased rumen pools of pdNDF, starch, OM, DM, and rumen digesta wet weight and volume and decreased ruminating time per unit of forage NDF consumed compared with OG, suggesting that alfalfa provided less physically effective fiber than orchardgrass. The AL diet interacted with level of feed intake to affect passage rate of iNDF and site of digestion of pdNDF and OM compared with OG. Passage rate of iNDF was related to pDMI such that AL increased iNDF passage rate and OG decreased it as pDMI increased. Ammonia N, NANMN, and NAN fluxes were increased by $\mathrm{AL}$, but not $\mathrm{OG}$, as pDMI increased. Digestion responses to forage family were affected by nutrient demand of cows.

\section{ACKNOWLEDGMENTS}

This project was supported by National Research Initiative Competitive Grant no. 2006-35206-16708 from the US Department of Agriculture National Institute of Food and Agriculture (Washington, DC). The authors thank N. K. Ames (Department of Large Animal Clinical Science, College of Veterinary Medicine, Michigan State University) for performing duodenal and ruminal cannulation surgeries, D. G. Main, R. A. Longuski, Y. Ying (Department of Animal Science, Michigan State University), and R. E. Kreft and the staff of the Michigan State University Dairy Cattle Teaching and Research Center (East Lansing) for their technical assistance and support, Barenbrug USA (Tangent, OR) for their donation of Baridana orchardgrass seed, and West Central Soy Cooperative (Ralston, IA) for donating the SoyPLUS protein supplement.

\section{REFERENCES}

Allen, M. S. 1996. Physical constraints on voluntary intake of forages by ruminants. J. Anim. Sci. 74:3063-3075.

Allen, M. S. 1997. Relationship between fermentation acid production in the rumen and the requirement for physically effective fiber. J. Dairy Sci. 80:1447-1462.

Allen, M. S. 2000. Effects of diet on short-term regulation of feed intake by lactating dairy cattle. J. Dairy Sci. 83:1598-1624.

Broderick, G. A., and J. H. Kang. 1980. Automated simultaneous determination of ammonia and total amino acids in rumen fluid and in vitro media. J. Dairy Sci. 63:64-75.

Buxton, D. R., and D. D. Redfearn. 1997. Plant limitations to fiber digestion and utilization. J. Nutr. 127:814S-818S. 
Clark, J. H., T. H. Klusmeyer, and M. R. Cameron. 1992. Microbial protein synthesis and flows of nitrogen fractions to the duodenum of dairy cows. J. Dairy Sci. 75:2304-2323.

Cochran, R. C., D. C. Adams, J. D. Wallace, and M. L. Galyean. 1986. Predicting digestibility of different diets with internal markers: Evaluation of four potential markers. J. Anim. Sci. 63:1476-1483.

Crawford, R. J., Jr., W. H. Hoover, and L. L. Junkins. 1980. Effects of solids and liquid flows on fermentation in continuous cultures. II. Nitrogen partitioning and efficiency of microbial synthesis. J. Anim. Sci. 51:986-995.

Dado, R. G., and M. S. Allen. 1994. Variation in and relationships among feeding, chewing, and drinking variables for lactating dairy cows. J. Dairy Sci. 77:132-144.

Goering, H. K., and P. J. Van Soest. 1970. Forage Fiber Analysis (Apparatus, Reagents, Procedures, and Some Applications). Agric Handbook No. 379. US Department of Agriculture-Agricultural Research Service, Washington, DC.

Hach, C. C., B. K. Bowden, A. B. Kopelove, and S. V. Brayton. 1987. More powerful peroxide Kjeldahl digestion method. J. Assoc. Off. Anal. Chem. 70:783-787.

Huhtanen, P., and S. Jaakkola. 1993. The effects of forage preservation method and proportion of concentrate on digestion of cell wall carbohydrates and rumen digesta pool size in cattle. Grass Forage Sci. $48: 155-165$

Jasaitis, D. K., J. E. Wohlt, and J. L. Evans. 1987. Influence of feed ion content on buffering capacity of ruminant feedstuffs in vitro. J. Dairy Sci. 70:1391-1403.

Joy, M. T., E. J. DePeters, J. G. Fadel, and R. A. Zinn. 1997. Effects of corn processing on the site and extent of digestion in lactating cows. J. Dairy Sci. 80:2087-2097.

Kammes, K. L., and M. S. Allen. 2012. Rates of particle size reduction and passage are faster for legume compared with cool-season grass, resulting in lower rumen fill and less effective fiber. J. Dairy Sci. 95:3288-3297. http://dx.doi.org/10.3168/jds.2011-5022.

Karkalas, J. 1985. An improved enzymatic method for the determination of native and modified starch. J. Sci. Food Agric. 36:10191027.

Krizsan, S. J., S. Ahvenjärvi, and P. Huhtanen. 2010. A meta-analysis of passage rate estimated by rumen evacuation with cattle and evaluation of passage rate prediction models. J. Dairy Sci. 93:5890-5901.

Lammers, B. P., D. R. Buckmaster, and A. J. Heinrichs. 1996. A simplified method for the analysis of particle sizes of forage and total mixed rations. J. Dairy Sci. 79:922-928.

Mertens, D. R. 2002. Gravimetric determination of amylase-treated neutral detergent fiber in feeds using refluxing in beakers or crucibles: Collaborative study. J. AOAC Int. 85:1217-1240.

Oba, M., and M. S. Allen. 1999. Evaluation of the importance of the digestibility of neutral detergent fiber from forage: Effects on dry matter intake and milk yield of dairy cows. J. Dairy Sci. $82: 589-596$

Oba, M., and M. S. Allen. 2003a. Effects of corn grain conservation method on feeding behavior and productivity of lactating dairy cows at two dietary starch concentrations. J. Dairy Sci. 86:174183.

Oba, M., and M. S. Allen. 2003b. Effects of corn grain conservation method on ruminal digestion kinetics for lactating dairy cows at two dietary starch concentrations. J. Dairy Sci. 86:184-194.
Oba, M., and M. S. Allen. 2003c. Effects of diet fermentability on efficiency of microbial nitrogen production in lactating dairy cows. J. Dairy Sci. 86:195-207.

Poore, M. H., J. A. Moore, T. P. Eck, R. S. Swingle, and C. B. Theurer. 1993. Effect of fiber source and ruminal starch degradability on site and extent of digestion in dairy cows. J. Dairy Sci. $76: 2244-2253$.

Robinson, P. J., S. Tamminga, and A. M. van Vuuren. 1987. Influence of declining level of feed intake and varying proportion of starch in the concentrate on rumen ingesta quantity, composition and kinetics of ingesta turnover in dairy cows. Livest. Prod. Sci. 17:37-62.

Russell, J. B., W. G. Bottje, and M. A. Cotta. 1981. Degradation of protein by mixed cultures of rumen bacteria: Identification of Streptococcus bovis as an actively proteolytic rumen bacterium. J. Anim. Sci. 53:242-252.

Russell, J. B., and G. M. Cook. 1995. Energetics of bacterial growth: Balance of anabolic and catabolic reactions. Microbiol. Rev 59:48-62

Shriver, B. J., W. H. Hoover, J. P. Sargent, R. J. Crawford Jr., and W. V. Thayne. 1986. Fermentation of a high concentrate diet as affected by ruminal $\mathrm{pH}$ and digesta flow. J. Dairy Sci. 69:413-419.

Steinshamn, H. 2010. Effect of forage legumes on feed intake, milk production, and milk quality-A review. Anim. Sci. Pap. Rep. $28: 195-206$.

Stensig, T., and P. H. Robinson. 1997. Digestion and passage kinetics of forage fiber in dairy cows as affected by fiber-free concentrate in the diet. J. Dairy Sci. 80:1339-1352.

Taylor, C. C., and M. S. Allen. 2005. Corn grain endosperm type and brown midrib 3 corn silage: Ruminal fermentation and N partitioning in lactating cows. J. Dairy Sci. 88:1434-1442.

Van Soest, P. J. 1982. Nutritional Ecology of the Ruminant. O \& B Books Inc., Corvallis, OR.

Voelker, J. A., and M. S. Allen. 2003. Pelleted beet pulp substituted for high-moisture corn: 3 . Effects of ruminal fermentation, $\mathrm{pH}$, and microbial protein efficiency in lactating dairy cows. J. Dairy Sci $86: 3562-3570$.

Voelker Linton, J. A., and M. S. Allen. 2008. Nutrient demand interacts with forage family to affect intake and digestion responses in dairy cows. J. Dairy Sci. 91:2694-2701.

Wildman, E. E., G. M. Jones, P. E. Wagner, R. L. Boman, H. F Troutt Jr., and T. N. Lesch. 1982. A dairy cow body condition scoring system and its relationship to selected production characteristics. J. Dairy Sci. 65:495-501.

Wilson, J. R., and R. D. Hatfield. 1997. Structural and chemical changes of cell wall types during stem development: Consequences for fibre degradation by rumen microflora. Aust. J. Agric. Res. 48:165-180.

Wilson, J. R., and P. M. Kennedy. 1996. Plant and animal constraints to voluntary feed intake associated with fibre characteristics and particle breakdown and passage in ruminants. Aust. J. Agric. Res. $47: 199-225$.

Zinn, R. A., and F. N. Owens. 1986. A rapid procedure for purine measurement and its use for estimating net ruminal protein synthesis. Can. J. Anim. Sci. 66:157-166. 